\title{
SOIL BIOREMEDIATION BY CYCLODEXTRINS. A REVIEW.
}

E. Morillo*, F. Madrid, A. Lara-Moreno, J. Villaverde

Institute of Natural Resources and Agrobiology of Seville (IRNAS-CSIC). Av. Reina Mercedes, 10. Sevilla. E-41012, Spain

*Corresponding author: morillo@irnase.csic.es

Keywords: Bioremediation, organic pollutants, soil contamination, cyclodextrins, bioavailability

\begin{abstract}
Remediation of soils contaminated by organic pollutants has become an urgent necessity worldwide. A wide variety of techniques have been developed but many of them are associated with drawbacks (complexity, high costs, environmental risks, etc.). Bioremediation, the use of living organisms to remediate polluted sites, is an alternative approach considered a cost-effective and more environmentally friendly technique, but the low bioavailability of the organic pollutants in soils is its main limitation. Cyclodextrins have been proposed as a 'greener' alternative to organic solvents or synthetic surfactants for increasing organics bioavailability in soils. Cyclodextrins can form inclusion complexes with hydrophobic pollutants increasing their aqueous solubility and enhancing their bioremediation in soils. This review gives an overview on the use of cyclodextrins for this purpose, highlighting the advantages and disadvantages and perspectives of this technology for future research. The effect of those cyclodextrins more commonly used is analyzed, particularly hydroxypropyl- $\beta$-cyclodextrin (HPBCD) and randomly methylated- $\beta$-cyclodextrin (RAMEB), as well as some of the more common contaminants treated (almost $80 \%$ are industrial chemicals and the rest are pesticides) and the bioremediation strategies used (by microorganisms and/or phytoremediation). The review also provides a critical view on knowledge gaps and limitations of this technology which must be overcome to bring it for field-scale application.
\end{abstract}




\section{Contents}

1. Organic contaminants in soils

1.1. Adsorption and aging of organic contaminants in soils

1.2. Methods for remediation of soil organic contaminants

2. Cyclodextrins

3. Use of cyclodextrins in soil remediation

4. Bioremediation of soils by cyclodextrins

4.1. Bioavailability of organic contaminants in soils

4.2. Cyclodextrins in soil bioremediation by microorganisms

4.2.1. Laboratory and microcosms experiments

4.2.2. Field experiments

4.3. Cyclodextrins in soil phytoremediation

5. Summary and Conclusions

Acknowledgements

References 


\section{Organic contaminants in soils}

Every year, thousands of sites in the world are contaminated by organic compounds which reach the soil surface. Pollution of soils is currently a significant concern worldwide because contaminants accumulate in the soil at unacceptably high levels, being a hazard to human health and the environment. It is well known that soils are major dumps for organic contaminants from different origins and characteristics. The main sources of pollution come from agriculture, industrial wastes and effluents, and urban activities.

The sources of industrial pollution include accidental breakage of storage tanks, continuous spillages from industry and improper disposal of industrial waste, including also electronic waste or littering, with the consequent seepages from landfills (Saxena and Bharagava, 2017). In regard to pollution due to urban activities, it has to be mentioned the contamination coming from an excessive use of plastics and other wastes, the disposal of urban wastewater to soil, including the improper discharge of pharmaceutical and personal care products, or the atmospheric deposition of pollutants, resulting in diffuse pollution that is cause of great concern because decontamination treatments are not possible, only prevention (Martínez-Bravo and Martínez-del-Río, 2019). And finally, agricultural pollution of the soil, that do not only come from an excessive application of pesticides, but also from the use of polluted water for irrigation or the application of biosolids generated by wastewater treatment plants and other organic fertilizers from livestock farms (Morillo and Villaverde, 2017). All these sources of soil pollution have a subsequent impact on the quality of groundwater and associated ecosystems, endangering fauna, flora and human health (Landy et al., 2012). Therefore, the problem of contamination of soil and groundwater is one of the fundamental aspects of protection of the environment.

A wide variety of organic contaminants are currently found in soils, but those of major concern are the contaminants which are very persistent in the environment due to their high hydrophobicity. From the Stockholm Convention (Stockholm Convention on POPs, 2011) some organic contaminants have been classified as Persistent Organic Pollutants (POPs), which were proposed for their disposal and/or prohibition and are being phased out of circulation. The most common POPs found in soils include: petroleum hydrocarbons (e.g., alkanes, alkenes, cycloalkanes), chlorinated compounds (e.g., PCBs, PCDDs, and PCDFs), monomeric aromatic hydrocarbons (e.g., benzene, toluene, 
ethylbenzene, and xylene, collectively known as BTEX), PAHs, organochlorine pesticides, etc. The main characteristics of POPs are their high resistance to physical, chemical and/or biological degradation, high persistence in the environment for long periods of time, their capacity to concentrate in living organisms (bioaccumulation) and biomagnify in the food chain, their high capacity of movement through different environmental compartments, and high adsorption on soil organic matter, and their toxic properties, because they are considered carcinogenic, mutagenic or reproductively toxic compounds as well as endocrine disrupters (Weber et al., 2015).

In addition to these "traditional" POPs, new chemicals are being manufactured to meet human beneficial purposes namely pharmaceutical and personal care products (toothpastes, soaps, perfumes, deodorants), artificial sweeteners, flame retardants, insect repellents, drugs, surfactants, disinfection products, plasticisers, microplastics, among others (Snow et al., 2017). These groups of substances have collectively been called emerging contaminants. Examples of emerging contaminants with potential relevance for soil, sediment and groundwater are: perfluoroalkyl substances (PFAS), nanoparticles, human and veterinary pharmaceuticals, pesticides, flame retardants, plasticizers, cosmetics and detergents. With advances in analytical techniques, a wide number of previously undetected compounds in soils have been identified and quantified. Most of these chemicals of emerging concern are not yet properly regulated, but their entry routes in soils are similar to those of POPs. The common characteristic of both traditional and emerging pollutants in soil is that they have an anthropogenic origin.

\subsection{Adsorption and aging of organic contaminants in soils}

Once the pollutants have reached the soil surface they can suffer different processes such as sorption-desorption, volatilization, absorption by plants, discharge runoff and leaching, or photo-, chemical and biological degradation. Such processes influence the subsequent behaviour and evolution of the pollutants not only in the soil, but also in the environment. The most important process is the adsorption-desorption to soil particles, because many other processes depend on this equilibrium. The higher the adsorption to soil, the lower the possibility of other processes to happen, and hence the lower the possibility of decontamination of the soil (Semple et al., 2004). One of the main factors which affect 
the contamination of soils is the nature and properties of the contaminants (polarity, solubility, degradability, etc.), which determine their possibility to be easily adsorbed by the soil or to be quickly degraded in the environment. Another important factor is the soil and its properties, such as texture, organic matter and carbonates content, $\mathrm{pH}$, the presence of oxides, microorganism population, etc. In the case of hydrophobic organic contaminants, their adsorption takes place mainly on the organic matter of the soil mainly through strong hydrophobic bonds. Moreover, when organic pollutants are adsorbed on soil surfaces, an aging process takes place, in which a fraction of the pollutant penetrates into the inner pores of soil aggregates through diffusion processes, reaching more energetic adsorption points. As time increases desorption of the contaminants from soil becomes more difficult.

\subsection{Methods for remediation of soil organic contaminants.}

Due to these aging processes, the availability of the pollutants to be remediated in contaminated soils is reduced, and, as a consequence, soil decontamination becomes more difficult, being necessary the use of agents and strategies to increase the availability of the pollutants to be removed from the soil (separation technologies) or eliminated in the soil (destructive technologies) (Morillo and Villaverde, 2017). Among physicochemical technologies based on mobilization are the following (Fenyvesi et al., 2019): soil venting, air stripping/sparging, soil washing/chemical extraction, or soil flushing (including electrokinetic extraction). However, destructive technologies for remediation of organic pollutants in soil can be divided into physicochemical technologies (including chemical degradation) and biological technologies (biological degradation). The efficiency of many of all these technologies can be enhanced by using extractants and solubilizing agents to make the contaminants more available to be treated with such technologies. According to Molnar et al. (2019) the most commonly used extractants are organic solvents, synthetic surfactants, biosurfactants, complex-forming agents, emulsifiers, micelle-forming agents, dendrimers and cyclodextrins (CDs). Some of them have certain disadvantages. For instance, organic solvents have toxic effects on the soil microbiota, and many synthetic surfactants are poorly biodegradable and remain adsorbed on soils, decreasing their effectivity, or are toxic to soil microorganisms, mainly the cationic ones. More recently, special attention has been given to biosurfactants and CDs, especially for the bioremediation of soils since they are more ecologically acceptable. They are 
biocompatible and favorable to the subsequent utilization of soils because they do not harm resident microbial populations.

\section{Cyclodextrins}

CDs are cyclic oligosaccharides obtained from the enzymatic degradation of starch. They are composed of glucose units associated by $\alpha-1,4$-glycosidic bonds, linked covalently by oxygen atoms and held via hydrogen bonding between the secondary hydroxyl groups on adjacent units at the wider rim of the cavity (the primary hydroxyl groups are situated in the narrower hydrophilic periphery). The main representatives, the so-called native CDs, are $\alpha-, \beta$ - and $\gamma$-CDs with 6-8 glucose units, respectively. They form a toroid shape, with hydrophilic faces, due to the presence of primary and secondary hydroxyl groups, and hydrophobic interior cavity capable of encapsulating hydrophobic organic molecules through host-guest interactions (Crini et al., 2014; Mallard et al., 2015). The encapsulated molecules are oriented to maximize the contact between their hydrophobic parts and the apolar CD cavity, the most hydrophobic part of the host molecule being preferentially included. The more hydrophobic the guest molecule, the more stable the complex will be. In addition to hydrophobic interactions, van der Waals interactions predominate in the formation of complexes with respect to steric effects and hydrogen bonding (Rekharsky and Inoue, 1998). In that way, an equilibrium between complexed and free species is established, being the inclusion a dynamic process (Landy et al., 2012).

Metal-CD complexes can also be formed. The large number of primary and secondary hydroxyl groups in native CDs provides coordination sites to chelate metal ions and form covalent bonds at basic $\mathrm{pH}$, where the $\mathrm{OH}$ groups can be deprotonated and act as nucleophiles. The formation of intra- and/or intermolecular hydrogen bonds can influence the mode of aggregation and supramolecular arrangement of the resulting metal complexes (Prochowicz et al., 2016). CDs can promote the removal of metals from contaminated solutions and from soils (Sun et al., 2013a; Ye et al., 2014b).

It has to be mentioned that CDs could also be used in preparing active polymers because many reactive groups on CDs allow forming them (Tian and Liu, 2020). They have application mainly in catalysis, drugs, food, materials and also in environment, but only 
related to their use as adsorbents for the removal of a variety of organic contaminants in wastewater treatment (Ling et al., 2020).

Morillo et al. (2012) observed a significant correlation between the capacity of solubilisation of six different PAHs and the fit of each PAH molecule within the cavity of the three different CDs. They also concluded that complexation energy and van der Waals energies were correlated in the majority of cases, confirming the van der Waals interactions were driving forces of complexation between PAH and CDs under the proposed microcosm. Liu and Guo (2002) showed that the water present inside the cavity did not intervene in the formation of the inclusion complex.

$\beta$-cyclodextrin (BCD) is the most studied and used $\mathrm{CD}$ for forming $\mathrm{CD}$ inclusion complexes with organic compounds, various molecules, ions, and polymers (Crini et al., 2018). Because of its low solubility in water, intermediate size, favorable hydrogen bond localization, greater complexation ability and low-cost, this $\mathrm{CD}$ is the first material of choice for environmental studies.

Also, various new synthesized CDs have been developed by methylation, aminations, esterifications, or etherifications of primary and secondary hydroxyl groups on the CDs, etc (Martín del Valle, 2004). The hydroxyl groups may be modified to get changes in the specificity and physical and chemical properties of the different parent CDs. In particular, the 6-OH groups are the most easily derivatized for making CDs with improved solubility. The solubility of CDs derivatives varies by the substituent and possession of a changed hydrophobic cavity (Szejtli, 1998).

Biodegradability of CDs plays a very important role when they are used in the environment. It would be desirable that the compound used as solubility-enhancer of the organic contaminant were biodegradable until it is no longer useful for removal process, that is to say, until bioavailability of the pollutant were increased. Native CDs are moderately biodegradable by microorganisms due to their glucose composition, and also their biodegradability is considered as similar. In general, chemically modified CDs show a lower biodegradability in both water and soil. However, some of them are able to resist during a few months after application, what is very convenient to increase their effectiveness as soil bioavailability enhancer during the decontamination treatment (Fenyvesi et al., 2005, 2009a). Hydroxypropyl-BCD (HPBCD) and Randomly 
methylated BCD (RAMEB) have an important capability to increase the hydrosolubility of hydrocarbons and other organic pollutants, which has been broadly reported in literature (Molnar et al., 2002; Fava et al., 2002; Hu et al., 2016), but on the contrary, they were found to be poorly biodegradable or exhibit a prolonged biodegradation by microflora at a large cellular concentration (Fenyvesi et al., 2005). From an environmental point of view, it is important to take into account the longevity of active CD species in contaminated sites to reach a significant decreasing of the concentration of pollutants. Fenyvesi et al. (2005) concluded that all CDs were found to be more or less biodegradable; and their biodegradability would depend on the microcosm conditions, even in the case of the most persistent RAMEB, which was biodegraded from soils under favorable conditions. In particular, in the performed field experiments, the dissipation of RAMEB reached about $40 \%$ of its initial level for a period of 2 years in hydrocarbon contaminated soils. In conclusion, the derivatization reactions of CDs provoked an improvement of the remediation of environmental pollutants, extending the half-life of this synthetized CDs throughout of the treatment application. Yuan \& Jin (2007) showed that the HPBCD biodegradation rate was always higher in contaminated than in uncontaminated soils. In general, CDs are biocompatible and favorable to the subsequent utilization of soils and, therefore, more ecologically acceptable, because they do not harm resident microbial populations, being approved as non-toxic compounds.

\section{Use of cyclodextrins in soil remediation}

Extensive work has been devoted to the development of remediation techniques for efficient contaminant removal or to reduce their contents to a safe and acceptable level once the soil gets polluted by organic contaminants. Different in situ and ex situ physical, chemical and biological technologies can be used for their remediation. The selection of the appropriate technique depends on factors such as type of contaminant and concentration, extension of the contamination (diffuse or point source), site characteristics, and the end use of the contaminated soil, among others. In general, treatment technologies to remove contaminants from soils are divided into separation technologies or destruction technologies, and in all of them CDs can be applied. CDtechnologies are applied ex situ (with the need to excavate and transport the soil for its treatment), but also in situ and on site, which are preferred for treating contaminated soils 
because of their lower cost, and for being least harmful for workers and the environment (Gomes et al., 2013).

Cyclodextrins have demonstrated to be powerful solubility enhancers of a wide variety of organic contaminants when they form inclusion complexes (Ginés et al., 1996; Villaverde et al., 2005a; Balogh et al., 2007; Yáñez et al., 2012; Ren et al., 2016; Zhang et al., 2019). Two key factors are important for CDs to form inclusion complexes with the guest molecules: the steric factor, which depends on the relative size of the $\mathrm{CD}$ as compared to the size of the guest molecule, or certain key functional groups within the guest; and the thermodynamic interactions between the different components of the system (CD, guest, solvent) (Martín del Valle, 2004). In the case of PAHs, proposed by the Stockholm Convention as POPs, Morillo et al. (2012) studied the solubilisation of six of them (with 3- and 4-rings) by three synthetic CDs: HPBCD, RAMEB and hydroxypropyl- $\gamma$-cyclodextrin (HPGCD). Although the three CDs greatly enhanced the apparent water solubility of all the PAHs tested, some of the latter (phenanthrene, anthrathene, fluorene) clearly presented a higher solubility when HPBCD and RAMEB were used, due to their more adequate molecular size and shape that allowed a strong interaction with the active centers in these CDs cavity. On the contrary, pyrene (PYR), a more voluminous molecule, presented its best solubility results when using HPGCD.

In the separation technologies, the contaminated soil is washed using solutions of CDs as extractant to remove the organic pollutants (Pérez-Martínez et al., 1999; Villaverde et al., 2005b, 2006; Fenyvesi et al., 2009). After washing, the CD-solutions containing the contaminants are separated from the soil and are regenerated or sent to landfill (Mousset et al., 2014a). The different increase in PAHs solubility by different CDs observed by Morillo et al. (2012) gives as result different extraction percentages when such CDs were used as extractants in an industrially contaminated soil (Sánchez-Trujillo et al., 2013). The highest extraction percentages were obtained for 3-ring PAHs, because of the appropriate size and shape of these compounds relative to the $\mathrm{CD}$ cavities. A drastic reduction in PAHs extraction was observed as their molecular weight increased, due to the steric hindrance, which limits the penetration of the contaminant into the CD cavity, and to their higher hydrophobicity, with greater tendency to remain adsorbed on the soil organic matter, presenting a lower extractability. Morillo et al. (2014) carried out desorption experiments of PAHs from aged contaminated soils concluding that soils with lower organic matter $(\mathrm{OM})$ content that had more diagenetically processed $\mathrm{OM}$ could 
block the extraction of PAHs more effectively than soils with higher and less humified OM content.

Methyl- $\beta$-cyclodextrin (MBCD) was also found to extract from a soil co-contaminated by electronic-waste pollutants most of the polybrominated diphenyl ethers (PBDEs), polychlorinated biphenyls (PCBs), PAHs, and metals ( $\mathrm{Pb}, \mathrm{Cu}$, and $\mathrm{Ni}$ ) by ultrasoundassisted soil washing (Chen et al., 2016a). The effect of several CDs was evaluated by Madrid et al. (2019b) on the removal of PAHs and potentially toxic elements (PTEs) from a co-contaminated soil which had received historically creosote and inorganic wood preservatives for almost 100 years. They observed that 4-ring PAHs were those extracted in higher concentrations, but the CDs used (BCD, HPBCD, HPGCD, RAMEB) had no effect on PTEs extraction.

Organochlorine pesticides have also been classified as POPs, and their production and use restricted. The insecticide DDT is one of those most abused of this family, and was banned by US EPA in 1973. However, there are still many soils contaminated by DDT. Ren et al. (2016) demonstrated the ability of $\alpha-, \beta-$, and $\gamma-\mathrm{CD}$ to improve DDT solubility, but observed that only $\alpha-C D$ allowed DDT to be readily disassociated from the inclusion complex, promoting DDT bioavailability and biodegradation by increasing its cell membrane permeation. The extraction from soils of many other pesticides have been obtained using CDs. Recently, Kaur and Kaur (2020) have studied the removal of the herbicides imazethapyr and imazamox from soils using BCD, chitosan and their biocomposites concluding that chitosan-BCD biocomposite can be regarded as effective and environmentally friendly in situ green extracting agent for remediating soils contaminated with imazethapyr and imazamox.

Other contaminants proposed by the Stockholm Convention to be eliminated from the environment are nonylphenol (NP) and nonylphenol ethoxylates (NPE), banned in the European Union since 2003 due to their endocrine disrupting properties. NPEs are used as nonionic surfactants in a large variety of industrial and domestic applications, principally for the manufacture of cleaning and disinfection products, but they are also used in the production of paper pulp, textile products, leather, and as additives in latex paints and pesticides (Lu and Gan, 2014). Biodegradation of NPEs leads to an increase in the concentration of NP that is often found in sewage sludge from wastewater treatments plants (WWTPs). Sánchez-Trujillo et al. (2014) observed that HPBCD forms inclusion 
complexes with NP increasing its solubility more than 5 hundred-fold, giving an increase in its extraction from sewage sludge up to $100 \%$, while with water the extraction was lower than $1 \%$.

In the destruction technologies we can distinguish between chemical and biological remediation. In chemical remediation, a variety of reactions, such as ionization, hydrolysis or oxidation-reduction, usually related to the $\mathrm{pH}$ value, are used to decompose the contaminants by breaking their molecule into other less toxic compounds or salts (Villaverde et al., 2007). Such remediation processes are called "advanced oxidation processes" (AOPs). There are not many papers combining simultaneous chemical extraction using CDs for removing POPs from soils and chemical reactions to destroy the contaminants, and would be considered then as separation technologies and treatment of the cyclodextrin solutions. Soils contaminated by PAHs (Ramsay et al., 2005; Mousset et al., 2014b), petroleum hydrocarbons (Wan et al., 2011; Zhang et al., 2020a), trichloroethylene (TCE) (Fenyvesi et al., 2011), pentachlorophenol (Hanna et al., 2005; Fukushima and Tatsumi., 2007), or electronic wastes containing PCBs, PAHs and PBDEs (Chen et al., 2017) have been treated using CDs and AOPs. Chen et al. (2019) investigated the influences of citric acid and MBCD as enhancing agents during the electrokinetic (EK)-persulfate process on the remediation of soil artificially contaminated with decabromodiphenyl ether (BDE-209) and copper $(\mathrm{Cu})$, observing that MBCD and citric acid could increase soil electrical current and electroosmotic flow during EK process, with a significant removal of BDE-209 and $\mathrm{Cu}$ from the soil.

Unlike chemical remediation, the role of $\mathrm{CDs}$ in biological remediation is quite important.Conventional techniques used for remediation of organic pollutants in soil such as soil washing/flushing or chemical decomposition are effective. However, they are also associated with many drawbacks such as their complexity and high costs, and some may pose environmental risks; consequently, public acceptance of these technologies is often low. Therefore, alternative 'greener' remediation approaches, low cost and easy methods are in increasing demand.

There are advantages and limitations of the use of CDs in soil remediation. The main advantage of the use of CDs is the increase of contaminant hydrosolubility and availability (Morillo et al., 2012, Zhao et al., 2015), but there are others: CDs generally used are not sensitive to changes in $\mathrm{pH}$ or ionic strength in soil solution; no formation of 
high-viscosity emulsions, as occurs for example with synthetic surfactants; CDs are minimally adsorbed on soil particles (Badr et al., 2004; Petitgirard et al., 2009) and there is no negative effect on soil properties (Jozefaciuk et al., 2001, 2003); or their very low toxicity for soil microbial populations (Tian et al., 2019) and high biodegradability, which minimizes the extractant residual in soil (Verstichel et al., 2004; Fenyvesi et al., 2005).

In relation with limitations or drawbacks of the use of CDs in soil remediation, it has to be mentioned those limitations coming from the CDs characteristics and properties themselves, such as the relative size of the $\mathrm{CD}$ as compared to the size of the guest molecule, since not all the pollutants molecules are suitable to be included in the CD hydrophobic cavity. Hydrophobicity of the guest molecule in relation to that of the cavity has also to be taken into account, since those guest molecules which present a high hydrophobicity will have a greater tendency to be included. A low hydrophobicity of the guest molecule will favour its interactions with other components of the system (water, soil) than with $\mathrm{CD}$. Another limitation point is related to the toxicity of the pollutant. If the CD selected can extract very high amounts of the pollutant towards the soil solution, such high concentrations could become toxic for the soil microbiota. In such cases, the concentration of the CD used plays an important role to get a successful remediation, as will be seen below.

\section{Bioremediation of soils by cyclodextrins}

Soil Bioremediation consists in the use of living organisms to remediate polluted sites, and is considered a cost-effective and environmentally friendly remediation technique. Bioremediation of contaminants includes different techniques such as biodegradation using soil microorganisms, phytoremediation using plants, or vermiremediation using earthworms, although, as far as we know, the latter technique has not been used yet with CDs. In contaminated soils, biodegradation of organic pollutants is one of the most effective ways for their decontamination, where the indigenous organisms degrade the contaminants without intervention (what is called "natural attenuation"). However, for any bioremediation process to be possible, there are several basic factors which are major determinants to be met (Molnar et al., 2019): first of all, the presence in the soil of appropriate living organisms with the potential to degrade the target contaminant, which they will use as an energy and carbon source. The existence of optimal environmental 
conditions, such as water content, temperature and $\mathrm{pH}$ of the soil is also crucial. The presence of nutrients (nitrogen, phosphorus, trace elements) is also necessary to stimulate microbial activity and support the microbial cell growth and enzyme production. And finally, the availability of the target contaminant to the soil organisms will also be important, which will depend on the physicochemical properties of the contaminant, the soil properties, and aging of the contaminant in the soil. Although high concentrations of a pollutant may be present in a soil, not all of it may be bioavailable, and, therefore, its complete degradation might not be possible.

\subsection{Bioavailability of organic contaminants in soils}

The first process of key importance to achieve the organic contaminants elimination from soils is their mobilization. Due to their high hydrophobicity, many organic pollutants are poorly soluble or insoluble in water, and hence they are strongly bound to the soil particles, especially to the organic matter of soils, decreasing the rate of mass transfer from the solid to the aqueous phase, which greatly reduces their bioavailability and thus decreases their biodegradation rates. Semple et al. (2004) consider that a compound is bioavailable when "it is freely available to cross an organism's cellular membrane from the medium the organism inhabits at a given time". What is bioavailable is bioavailable now. Figure 1 presents a conceptual diagram adapted from Semple et al. (2004) which illustrates the bioavailable and non-bioavailable fractions of a contaminant in soil depending on its physical location on the soil particles after reaching the soil surface. Even a fraction of the pollutant molecules can reach more energetic adsorption points through diffusion processes (Villaverde et al., 2009), or they can penetrate into the interior of the soil aggregates, becoming completely occluded. In such cases, molecules show an almost complete resistance to be removed and biodegraded, what is considered as a recalcitrant molecule or non-extractable residue (Kastner et al., 2014), and the adsorption is non-reversible. These contaminant molecules are non-accessible for soil organism, and, therefore, non-bioavailable. In these cases, the soil is contaminated, but nevertheless these highly adsorbed fractions do not present problems of migration to other environmental phases, nor toxicity problems for living beings, including humans. They are not potentially toxic to the environment. 
But, between these two positions there is a third one, the bioaccessible molecules, which are those sorbed contaminants whose adsorption is slowly or very slowly reversible. They are temporarily constrained, but this implies that if they are accessible they can be reached by soil organisms, but are not available now at this moment. These chemicals may be either bioavailable after a period of time, or be removed from the soil by chemical or physical methods. This is the case of those hydrophobic pollutants proposed by the Stockholm Convention as Highly persistent in the environment for long periods of time.

It is necessary to enhance their solubility so that they can be removed from the soil or become accessible for further biodegradation by soil organisms. A low bioavailability is perhaps the main limitation for biodegradation of organic pollutants in soils.

Some extractants agents have been used to increase pollutants bioavailability. Addition of solubilizing agents such as cosolvents and surfactants is known to increase the transport of low-polarity organics from soils (Morillo and Villaverde, 2017). However, organic solvents and many synthetic organic surfactants present adverse environmental impacts because they are proved to be toxic and non-biodegradable, and surfactants may also form high viscosity emulsions that are difficult to remove (Yuan et al., 2014). And it is precisely in increasing the bioavailability of pollutants to soil organisms where CDs can play a key role in soil bioremediation. CDs have been proposed as alternative agents to remove organic pollutants from contaminated sites to avoid the problems derived from the use of other solubilizing agents (Fenyvesi et al., 2009a).

As bioavailability is the key to assess the percentage of a pollutant in soil which is available for uptake by organisms to be degraded, different physico-chemical studies have been proposed to predict the bioavailability of certain contaminants. Most studies involve extractions by shaking the soil with salt solutions or weakly polar solvents (methanol, nbutanol, etc.) to simulate soil solution (Villaverde et al., 2013a; Rubio-Bellido et al., 2018). But also some CDs have been used to measure bioavailability assessment of various organic pollutants (Stroud et al., 2009a,b; Hajdu et al., 2011; Nagy et al., 2013). Reid et al. (2000) developed a non-exhaustive extraction technique using HPBCD solutions to assess the microbial degradability of organic contaminants in soil. In this study, the microbially bioavailable concentrations of soil-associated phenanthrene were best predicted using the optimized HPBCD extraction technique (HPBCD concentration, extraction time, and solution buffering). The predictive power of HPBCD method has 
been observed by correlating this non-exhaustive extraction with biodegradation/mineralization of a specific organic pollutant in soil. This technique has been widely used for estimating the availability of a great variety of pollutants such as PAHs (Cuypers et al., 2002; Stokes et al., 2005; Allan et al., 2006, 2007; Sabaté et al., 2006; Doick et al., 2006; Papadopoulos et al., 2007; Bergknut et al., 2007; Rhodes et al., 2008; Mahmoudi et al., 2013; Lemaire et al., 2019; Leech et al., 2020), PCBs (Ti et al., 2018), or pesticides (Hartnik et al., 2008; Wong and Bidleman, 2011; Villaverde et al., 2013a; Rubio-Bellido et al., 2018).

\subsection{CDs in soil bioremediation by microorganisms}

Biodegradation of organic contaminants by microorganisms is the principal process responsible for their destruction in the soil, but natural biodegradation is usually a very slow process (Gruiz et al., 2019). There is a need to accelerate the biodegradation to remediate contaminated soils as soon as possible, and bioremediation is used for such acceleration. Bioremediation by microorganisms is a biotechnology procedure which uses the ability of microorganisms which are adapted to degrade pollutants in contaminated sites. Once the soil gets contaminated, the soil microbiota reacts immediately to the new condition, and those species capable of degrading the contaminant will proliferate, and those that can produce enzymes required for the degradation of the contaminant become activated. Microbes assimilate and metabolize chemical contaminants present in the soil into less complex molecules and use them as sources of carbon and energy. The complete degradation of such metabolites is their mineralization, which converts the organic compounds into their inorganic constituents (carbon dioxide and water under aerobic conditions, or methane in anaerobic conditions) or mineral salts, and new biomass for microbial growth.

Bioremediation offers an environmentally friendly and cost competitive approach for the clean-up of contaminated sites, although it used to be more time-consuming than other technologies more aggressive for the environment, such as chemical treatments or washing/flushing procedures. However, the effectiveness of soil bioremediation can be improved increasing the biological activity of the soil with optimum conditions for the biodegrading soil microbiota by enrichment with nutrients, fertilizers and/or oxygen, and increasing the bioavailability of the pollutants, giving as a result greater percentages of 
pollutant degradation and shorter treatment time (Megharaj et al., 2011). Another variation of this technology is the introduction into the contaminated site of exogenous microorganisms adapted in the laboratory for the degradation of a specific pollutant.

Therefore, there are advantages and disadvantages of the process of soil bioremediation by microorganisms. Among the advantages it has to be mentioned that the process is very easy to perform and has a low cost as compared to other remediation technologies. Moreover, as bioremediation is a natural process, it is perceived by the public as an acceptable waste treatment process for contaminated soils. Another point in favour of bioremediation is that this technique can be combined with other physicochemical technologies for improving its implementation, such as soil washing, or the use of some chemical products to extract the contaminants from the soil, such as synthetic surfactants, biosurfactants or cyclodextrins (Trellu et al., 2016).

However, there are also some disadvantages in the use of bioremediation of soils, and one of the most important is the long time required for a natural attenuation of the contaminant, what can be substantially improved with the aid of amendments, using the extractants previously mentioned, or controlling environmental and soil conditions to get those most favourable to the process. It also has to be considered that not all the contaminants are biodegradable. Therefore, a previous study of the organic contaminants present in the soil is needed in order to know whether bioremediation is the most adequate technology to be applied. The possible metabolites which can be generated after the bioremediation process could be more toxic than the pollutant initially present in the soil, and it has to be also taken into account. Fava and Ciccotosto (2002) observed an increased toxicity in soil contaminated by PCBs after their degradation using RAMEB because degraded PCBs were only partially dechlorinated, and very toxic metabolites persisted in soil. And finally, when using extractants as surfactants or CDs to improve the bioremediation processes, it has to be considered that the contaminant mobility increases, and, in this way the possibility of its leaching to groundwater, which can in turn be contaminated (Morillo et al., 2001; Rubio-Bellido et al., 2016; Báez et al., 2017).

For the use of CDs to improve the bioremediation of a polluted soil there are several main steps necessary to develop the technology until it can be applied in the field at a real scenario. Molnar et al. (2009) gave a very clear vision of the various stages with increasing scale of experiments that need to be overcome. Firstly, small-scale laboratory tests have to be performed during 1-3 weeks (depending on the test) and using about 50- 
$250 \mathrm{~g}$ of polluted soil. In a second stage, using the most efficient conditions deduced from the small-scale tests, technological experiments in microcosms containing between 250$500 \mathrm{~g}$ of soil are carried out during 4-10 weeks, in order to find the optimum parameters to perform the third stage, the pilot-scale technological experiments. To be able to follow the remediation over a long term, these experiments will be developed during several months, even during more than one year, using a huge amount of soil (more than 40-50 $\mathrm{kg}$ ) and with a variety of CDs concentrations, in order to select that which better results could give in the fourth and final step, field application.

The different studies carried out to date about the use of CDs in soil bioremediation by microorganisms are summarized in Tables 1-4 for various pollutants, PAHs (Table 1), pesticides (Table 2), PCBs (Table 3), and other contaminants (Table 4).

\subsubsection{Laboratory and microcosms experiments}

Extractability of the pollutants. In relation to the small-scale experiments, the first to be carried out are those related to the study of the increased solubility of the pollutant in the presence of certain CDs in aqueous solutions (Villaverde et al., 2012). If the result is positive with some of them, those CDs which presented the best results will be selected to carry out small-scale and microcosm laboratory experiments, normally using soils artificially spiked with the pollutant to be degraded, to test whether the CDs selected are able to extract it from the soil (Villaverde et al., 2012; Sun et al., 2013; Gao et al., 2015). Rubio-Bellido et al. (2016) studied the effectiveness of HPBCD to extract the herbicide diuron from seven soils that have been artificially contaminated. In all cases the extraction was more effective when using the $\mathrm{CD}$, but it depends on the type of soil and their characteristics. In those soils where diuron was easily extracted by water there was not much advantage in the use of HPBCD as extractant, and this CD was discarded for remediation of diuron. On the contrary, for other soils the $\mathrm{CD}$ used was quite effective in diuron extraction, and it was demonstrated when diuron biodegradation experiments were carried out, since a significant mineralization increase of the herbicide was observed in these soils. In one of the soils tested up to $45 \%$ of the herbicide was mineralized in the presence of $\mathrm{HPBCD}$, while in its absence the mineralized herbicide was only about $2 \%$, indicating the very high increase in bioavailability of the pollutant caused by the CD. With the extremely low mineralization results obtained in the experiment without CD, 
one might think that there is not an endogenous microbiota in this soil adapted to degrade diuron. But the high mineralization results obtained in the presence of HPBCD indicated the contrary, and also indicated that the degradation was impeded only due to the low bioavailability of the herbicide in this soil.

The most favorable CD concentration to be used is another aspect to be considered to increase the solubility and bioavailability of the organic pollutants in soils. Fava and Ciccotosto (2002) tested RAMEB concentrations at 0, 1, 3 and 5\% (w/w) in the aerobic bioremediation of three soils with different properties artificially contaminated by PCBs from transformer oil. RAMEB effects on the PCB biodegradation varied significantly with the type of soil, but it did not change linearly with the concentration at which RAMEB was applied, being maximal at a concentration of 3\%. They suggest that the achievement of some stoichiometric ratios between pollutant molecules and CDs is probably necessary for effective PCB solubilization in soil microcosms. An excess of CD applied can even give as a result an increase in toxicity. Fava et al. (2002) observed in one of the soils studied a decrease in PCBs degradation, and even a complete depletion in microbiological activity, as RAMEB concentration increased; but nevertheless, PCBs degradation in a different soil increased with RAMEB concentration. In the first soil, it was probably due to the fact that PCB-solubilising effects of RAMEB prevailed on PCBs biodegradation, concluding that the effect of the $\mathrm{CD}$ depended on the properties of the contaminant and those of the soil, including its microbiological properties. Molnar et al. (2005) observed that RAMEB significantly shortened the lag-phase in bioremediation of transformer oil polluted soils, especially when it was applied at concentration higher than $0.3-0.5 \%$. But they also observed a decrease in the concentration of specialized degrader biomass at higher $\mathrm{CD}$ concentrations due to the growing pollutant bioavailability and, therefore, toxicity. Sun et al. (2012) used MBCD amendments at rates 5\%, 10\%, 15\%, and $20 \%$ to treat a PAH-contaminated soil, and observed that $10 \%$ rate was the most favorable because PAH degrading bacteria in soil decreased with higher rates. On contrary, Simpanen et al. (2016) observed that a lower rate $(1 \% \mathrm{w} / \mathrm{w})$ of MBCD concentration was most feasible for soil bioremediation as most of the extracted PAH compounds were degraded. In the 5\% MBCD treatment, PAH desorption from soil was too fast compared to the degradation capacity, and $25 \%$ of the total $\mathrm{PAH}$ extracted remained in the soil solution. 
Biostimulation of soil microbiota. Addition of nutrients and micronutrients is an important factor to activate and increase the degradation of organic pollutants in soil. Nutrients, such as nitrogen and phosphorus in particular, are common additives used to enhance the rate of biodegradation in bioremediation applications, but bacterial cells require also micronutrients such as iron, sulfur, manganese, zinc, nickel, selenium and cobalt, among others (Megharaj et al., 2011; Villaverde et al., 2018). Small-scale laboratory experiments have to be performed to study the necessity of their addition for the success of the bioremediation process. Rubio-Bellido et al. (2015) observed that no mineralization of diuron occurred in a spiked soil until micronutrients were applied, activating the endogenous soil microflora and reaching $15.5 \%$ of mineralization. On the other hand, contaminated sites contain organic pollutants that are rich in carbon sources, but poor in nitrogen and phosphorus. To supply these nutrients, these researchers added compost from 2 organic residues to the spiked soil, and the mineralization increased as the rate of compost added was increased, reaching up to about $33 \%$ of diuron mineralization rate. And even more, the mineralization of diuron increased up to $46.5 \%$ when HPBCD and one of the composts were added together.

Humic substances (HS) were also used as amendment to increase soil organic matter and to supply energy and carbon sources to soil microbiota by Liu et al. (2018) together with the addition of HPBCD. They observed that PYR degradation increased from $28 \%$ in the control experiment to $40 \%$ in the presence of only HPBCD after 98 days, and benzo[a]pyrene (B[a]PYR) increased from $2.8 \%$ to $4 \%$. With the addition of only HS, the degradation of PYR and B[a]PYR increased up to 43.55 and 16\%, respectively. However, the joint presence of HPBCD + HS decreased PYR and B[a]PYR degradation to $32 \%$ and $10 \%$, respectively. They observed that HS promoted cell growth of soil bacteria greatly, but addition of HPBCD decreased the diversity of soil bacteria promoted by HS. It corroborates that all these laboratory experiments are needed to further confirm the CDs and amendments effect on bioremediation of organic contaminated soils previous to their application at field-scale.

In the case of PCBs degradation in soils, apart from the nutrients that can be added as biostimulation of microbial biomass in soil, their complete biodegradation in aerobic conditions generally requires to be amended with biphenyl as a co-substrate (Table 3). Biphenyl is believed to promote PCB degradation by inducing PCB-degrading enzyme synthesis and microbial growth, as confirmed by many studies (Fava et al., 1998, 2002, 
2003; Fedi et al., 2005). However, Luo et al. (2007) observed that HPBCD plus biphenyl treatment significantly reduced removal of di- and tri-chlorinated biphenyl in soils, which were highly enhanced by using only biphenyl. They supposed that HPBCD, as a carbon source, could suppress biphenyl-induced PCB degrading enzymes and/or PCB degrading microbial populations. These results contrasted with those previously mentioned in which biphenyl in combination with HPBCD generally enhanced PCB removal compared with biphenyl alone.

Bioaugmentation of soil. Continuing with the small scale laboratory experiments, bioaugmentation is one of the possibilities to improve the $\mathrm{CD}$ technology for soil bioremediation. Bioaugmentation is the addition of microorganisms cultures required to speed up the rate of degradation of a contaminant. A specific degrader microorganism of the contaminant or a consortium of degrader microorganisms can be selected (El Fantroussi and Agathos, 2005). A set of experiments have to be performed to prove different microorganisms with the ability to degrade the contaminant and also the conditions to improve their efficiency for biodegradation. The microorganisms added could be endogenous or exogenous. Endogenous microorganisms are those that normally exist in contaminated soils and have been adapted to use the contaminant as source of carbon and energy, so that they may already be able to break down this specific contaminant, but perhaps in low concentrations or not sufficiently activated for degrading significantly the contaminant. If this is the case, these microorganisms can be extracted from the soil, and their growth is enhanced in the laboratory (ex situ). After that, they are returned to the polluted soil in much greater concentrations. Reinoculation of such specific microorganisms might appreciably improve the decomposition of specific pollutants. Madrid et al. (2019a) isolated an endogenous microbial consortium degrader of PAHs from a long-term creosote contaminated soil, which was used as bioaugmentation to treat the same soil. Also Fava et al. (1998), Bardi et al. (2003) and Leitgib et al. (2003) used endogenous bacteria for bioaugmentation, but in most of those cases with endogenous microbiota, bioaugmentation is not used.

If, on the contrary, the polluted soil does not contain degrader microorganisms for a specific organic contaminant, it is necessary to look for exogenous microorganisms which degrade it. Such microorganisms can be extracted from other contaminated sites or from other ecosystems (Sopeña et al., 2014; Villaverde et al., 2017). Taccari et al. (2012) used 
bacterial strains isolated from an aged diesel-contaminated soil for remediation of an artificially spiked soil using BCD. Tian et al. (2019) used a bacterial consortium from an oil-contaminated soil enriched with PYR for bioremediation of PYR and B[a]PYR in an artificially spiked soil using MBCD. Villaverde et al. (2018) isolated five microbial degrading consortia through enrichment with the herbicide diuron of five agricultural soils with a record of pesticide application for more than 10 years. The isolated consortia were investigated for diuron mineralization in aqueous solution and soil slurries, and the consortia with better results were applied for soil bioremediation in static conditions $(40 \%$ of soil water-holding capacity), a more realistic scenario. The extent of mineralization in the soil using only biostimulation of endogenous soil microbiota with nutrients was about $13 \%$, which increased to $27 \%$ after addition of HPBCD as bioavailability enhancer, or up to $23 \%$ when the exogenous consortia selected were added, but reached up to $42 \%$ when HPBCD and the selected consortium were applied together.

Remediation in co-contaminated soils. Although single contaminants are rarely found in contaminated sites, the majority of biodegradation studies on polluted soils are designed to dissipate only a specific organic contaminant, but without describing the effect of the biodegradation process on the rest of other contaminants (organic or inorganic) present in the soil (Ye et al., 2017). In many contaminated soils exist not only organic contaminants, but also potentially toxic elements are present (PTEs), being currently a significant concern worldwide. The effect of any remediation treatment used for hydrophobic contaminants removal from co-contaminated soils will have effects on extraction and availability of PTEs present in the soil (Zhang et al., 2020b), and this fact has to be considered in order to avoid a secondary contamination of the surrounding environment or an increased toxicity in the treated soil which can affect to a subsequent bioremediation process. In these cases, it is important to develop appropriate remediation techniques to treat both pollutants, or at least to degrade the organics but without increasing availability of the inorganic pollutants. These techniques are usually more complex and costly due to the differences in the physicochemical properties of organic and inorganic contaminants.

Laboratory studies have shown the ability of some derivatives of CDs to complex metals (Skold et al., 2009; Prochowicz et al., 2016), and there are studies using CDs to extract simultaneously PTEs and hydrophobic contaminants from soils (Ehsan et al., 2007; Skold 
et al., 2008; Mouton et al., 2009; Yang et al., 2010; Wang et al., 2010; Sun et al., 2013a; Chen et al., 2016a; Zhang et al., 2019). However, there are rather fewer studies dealing with the effect of CDs applied to soils to biodegrade organic contaminants and their simultaneous effects on the PTEs present. Hoffman et al. (2010) showed that carboxymethyl- $\beta$-cyclodextrin $(\mathrm{CMBCD})$ could alleviate the toxicity of metals $(\mathrm{Cd}, \mathrm{Co}$ and $\mathrm{Cu}$ ) whereas it had the potential to strengthen biodegradation rates of naphthalene by enhancing its solubility and bioavailability.

Soils contaminated by creosote (used as a wood preserving agent for many years to treat railroad ties, power line poles or ship's hull to prevent rot) present organic and PTEs contamination. Creosote is a very complex mixture of organic compounds, being PAHs the main components (about $85 \%$ ), but also some PTEs ( $\mathrm{Cr}, \mathrm{Cu}$ or As) are used as wood preserving agents. The waste sludge produced by these treatments was generally landfilled, and these sites are nowadays brownfield of contaminated soil by PAHs and PTEs. Madrid et al. (2019a) studied the effect of the application of HPBCD in the biodegradation of PAHs in a creosote polluted soil co-contaminated with PTEs. Bioremediation experiments were carried out also with a rhamnolipid biosurfactant (RL) for comparison to HPBCD. 2- and 3-ring PAHs were almost absent from this soil because it had been subjected to natural attenuation for almost 100 years before the experiments, and it is likely that the volatile, water soluble and easily available PAHs were already removed. HPBCD could reduce especially the content of 4-ring PAHs, and up to 48\% degradation for PYR and $43 \%$ for fluoranthene (FLT) was achieved, and was proved to be inefficient for PTEs extraction. On the contrary, the percentage of PAHs degraded in the presence of the biosurfactant was null, and the reason was the toxicity of the soil after treatment with RL, since it had been previously demonstrated (Madrid et al., 2019b) that this biosurfactant could extract PTEs from the contaminated soil (up to $21 \%$ of $\mathrm{Cd}$, or $14 \% \mathrm{~Pb}, \mathrm{Zn}$, or $\mathrm{Ni}$, or $7 \%$ for $\mathrm{Cu}$ or $\mathrm{As}$ ), eliminating any microbial activity in the soil. This study revealed the advantage of using the CDs such as BCD, HPBCD and RAMEB as extractants instead of this biosurfactant in those co-contaminated soils where the release of PTEs is not convenient to prevent their leaching to groundwater or an increase of the soil toxicity for microbiota.

More than $95 \%$ of the studies with co-contaminated soils are carried out on soils polluted by organic and inorganic contaminants, but only few studies are designed to study the mutual influence on biodegradation behaviour of several organic pollutants that can be 
found in co-contaminated soils. Co-contaminated soils, both artificially spiked or real contaminated soils, are studied in some of the papers presented in Tables 1-4, but the mutual influence of some pollutants on the others is not the aim in them (Ye at al., 2014; Liu et al., 2018; Tian et al., 2019). On the contrary, Madrid et al. (2016) carried out smallscale experiments to study the mutual effect of pyrene and fluorene on their respective dissipation in soil. They observed that fluorene dissipation was primarily due to abiotic loss through volatilization, and, therefore, the presence of HPBCD had no influence on it. On the contrary, endogenous microorganisms were able to degrade pyrene, with a high increase in biodegradation rate when the $\mathrm{CD}$ was present. When the soil was contaminated with both PAHs, fluorene losses by volatilization had a significant effect on the soil microbial community, inhibiting significantly pyrene biodegradation. This study showed that experiments using single PAH do not reflect the complexity of their dissipation in natural environments.

\subsubsection{Field experiments}

Up to here, we have already discussed a number of studies which have shown the effect of CDs for improvement of bioavailability as an enhancer of bioremediation in laboratory or greenhouse experiments, but field demonstration is the peak of the increasing scale of the experiments. However, the general problem is that laboratory studies are not performed in a way that can be exactly reproduced in real clean-up cases. In laboratory or greenhouse studies, conditions are often optimal and the implementation of equal conditions in the field is challenging or impossible. Therefore, it is important to carry out field experiments. A technology can be excellent on one site, but absolutely not effective on another one, and this is the reason why a site-specific evaluation is so important. But, unfortunately, there are not many field studies using CDs to bioremediate contaminated soils. There have been more field experiments with CDs for decontamination of soils and sediments using washing or flushing methodologies (Ehsan et al., 2007; Boving et al., 2008; Ye et al., 2014b; Blanford et al., 2018), but not for bioremediation.

In this sense, the group of Fenyvesi, Molnar and Gruiz in Hungary has to be especially cited because they have carried out the most comprehensive studies in relation to field studies using CDs. The contaminated sites that they selected were located in a tank station in an agricultural site (Leitgib et al., 2008; Fenyvesi et al., 2009b) and in a former military site (Fenyvesi et al., 2010), both polluted with old diesel and engine oils, and the soil from 
a transformer station polluted with transformer oil (Molnar et al., 2005, 2009; Gruiz et al., 2009, 2010). An integrated chemical-biological-ecotoxicological methodology was applied to follow the bioremediation in the frame of the MOKKA project, in which not only in situ soil bioremediation was studied, but also decontamination of polluted groundwater was carried out. RAMEB was used as bioavalability enhancer for increasing the biodegradation and solubilization of hydrocarbon contaminants. The researchers used a technology assessment tool that evaluates the technological, environmental, ecological and cost-efficiency of the bioremediation technology, monitoring the amount of pollutant eliminated, the environmental risk for the surrounding environment, the toxicity of the contaminated soil before, during and after remediation, and the cost-benefit assessment of the complete process (Gruiz et al., 2007). It is worthy to point out the drastic decrease of the contaminants. In the soil contaminated with transformer oil about $99 \%$ of the contaminant was removed after 47 weeks of treatment, and in one of the soils contaminated by diesel and engine oils about $90 \%$ of the contaminant was remediated in 85 weeks.

The conclusions obtained in these field experiments were the following: (1) Enhanced removal of pollutants due to an increase in their bioavailability due to the presence of the CD; (2) Activating effect of RAMEB on soil microflora, observing a higher cell concentration in the treated soil; (3) the adaptation period of soil indigenous microflora (lag-phase) was shortened, giving as result a faster bioremediation and a shortened treatment-time, with a great difference in the duration of the treatment of 15 years for a natural attenuation in comparison to one year and a half when CD RAMEB was added (Gruiz et al., 2009); (4) the risk of the technology was lower than other technologies (dig and dump, ex situ treatments, in situ washing, use of chemical surfactants or solvents); (5) the cost-benefit assessment was more favourable for bioremediation than for other technologies, because of the great difference in the shorter period of time required to complete the remediation process, which compensates the price of the CDs used.

In relation to PAHs bioremediation in soils by CDs it has to be mentioned also the field studies carried out by Bardi et al. (2007) and Simpanen et al. (2016). Bardi et al. carried out a field study on a soil artificially spiked with diesel fuel, and observed the biodegradation of PAHs by the augmentation with a commercial microbial consortium and by the increase of PAHs bioavailability using BCD. They observed that BCD enhanced bioremediation, but the microbial consortium did not improve it. Simpanen et 
al. (2016) compared laboratory simulations to a full field scale application in environmental conditions for bioremediation of PAHs in a creosote contaminated soil on site. Soil remediation was based on the degradation capacity of the indigenous microbial community and biostimulation with nutrient amendments (calcium peroxide, methylene urea, salpetre) and MBCD. After 13 months of field experiment, they observed that PAHs concentration was reduced in the soil from 1100 to $790 \mathrm{mg} \mathrm{kg}^{-1}$ in the control experiment, to $420 \mathrm{mg} \mathrm{kg}^{-1}$ when using only nutrients, and in the presence of $1 \% \mathrm{MBCD}$ and nutrients it was reduced until $380 \mathrm{mg} \mathrm{kg}^{-1}$ (about $66 \%$ of reduction). They observed that those PAHs with the lowest molecular weights (those with 2-3 aromatic rings) could be degraded using only nutrients, but PAHs with 4-5 rings were only degraded if nutrients and the CD were used simultaneously. And finally, those compounds with more than 5 rings were poorly degraded, and their degradation was not improved by the addition of nutrients or the $\mathrm{CD}$. Therefore, they conclude that the advantage of using CDs may be to improve the degradation of particularly larger PAH compounds present in creosote contaminated soil, and that the most cost-efficient and practical bioremediation can be achieved by using the CD only at later stages, when the most available PAHs have been degraded and the more recalcitrant contaminants remain in the soil.

\subsection{Cyclodextrins in soil phytoremediation}

Up to now, we have seen the role of cyclodextrins in soil bioremediation by microorganisms, but bioremediation of contaminated soils is also possible using plants, which is called phytoremediation. However, there are very few studies about it, and most of them have been carried out in quite recent years (Table 5). Using phytoremediation, organic contaminants can be extracted from the soil (phytoextraction), immobilized (phytostabilization) or degraded (phytodegradation) (Gerhard et al., 2009). It is considered an environmentally friendly and economically effective option dealing with contaminated soils. The presence of plants significantly increases the biological activity of soils, increasing the microbial counts and enzymatic activity (Quin et al., 2016; Kong et al., 2018). However, there are some restrictions which may limit the phytoremediation efficiency. One of them is the low tolerance to environmental stress in plants due to the toxicity caused by the presence of the contaminant in soil. The second critical factor that limits the phytoremediation efficiency is the low bioavailability of pollutants in the soil. And this is the factor where CDs can play an important role. 
CDs can provide different effects to improve the phytoremediation of contaminated soils. First of all, they increase the bioavailability of organic pollutants towards the degrader microorganisms present in the soil. As a consequence, there is an enhancement in the removal of pollutants and the possibility of their plant uptake (Bardi et al., 2007; Wang et al., 2015; Li et al., 2018a). An additional advantage is that the encapsulation of the pollutants by CDs decrease their toxicity towards bacterial cells of microorganisms and plants, and the presence of CDs in the soil biostimulates the soil microbial activity because CDs are also carbon sources (Shen et al., 2009; Dahmer et al., 2018).

As far as we know, one of the first studies dealing with CDs in soil phytoremediation is that of Bardi et al. (2007), who wanted to know whether PAH uptake from plants is influenced by the presence of CD. After the field experiments carried out, they observed that traces of PAH were present in soybean seeds, suggesting that a hydrocarbon root uptake and xylematic translocation occurred. PAH content in seeds was higher and qualitatively different in the plot treated with BCD, due to the higher water-solubility of PAHs induced by the CD. An additional effect of symbiotic mycorrhizal fungi could also be hypothesized on increased plant uptake, concluding that in situ PAH bioremediation was improved by associating BCD to phytoremediation.

Chen et al. (2010) studied the effects of BCD on the removal of PCBs in a contaminated soil after four months of ryegrass growth. They observed that in unplanted soil no increase of PCB removal could be achieved by $\mathrm{CD}$, even using increasing concentrations. But after plantation of ryegrass together with BCD addition, PCB degradation increased, due to the biostimulation of microbial communities in the soil. The highest removal of PCBs was obtained with $1 \% \mathrm{BCD}(\mathrm{w} / \mathrm{w})$. At higher BCD concentrations, the contaminant bioavailability can be excessive, becoming toxic for the microorganisms. This study also demonstrated that PCB removal was mainly contributed by microbial degradation in the soil surrounding the roots of the plants, and not by plant uptake. This process is called rhizoremediation, which is the process where microorganisms degrade soil contaminants in the rhizosphere, which is the narrow region of soil that is directly influenced by root secretions and associated soil microorganisms, known as the root microbiome. Plant root exudates stimulate growth and metabolism of the rhizospheric microorganisms. In this study the authors used the indigenous root microorganisms, but the degradation process can be carried out by exogenous specific pollutant-degrader microorganisms. 
Phytoremediation in co-contaminated soils. As previously mentioned, the coexistence of organic and metal pollutants is frequent in many contaminated soils, and some studies have demonstrated the ability of phytoremediation to remove both contaminants from soils (Huang et al., 2011; Chen et al., 2016b), but also the effect of CDs for improving the removal of such contaminants (Ye et al., 2014b; Wang et al, 2015, 2018; Li et al., 2018b). Li et al. (2019) used BCD and inoculation of the soil with an exogenous fungus (Arbuscular Mycorrhizal fungus, AMF) to increase the phytoremediation process in an electronic-waste contaminated soil. This soil was co-contaminated with $\mathrm{Cd}$ and BDE209, a brominated flame retardant. The disposal of electronic waste leads to elevated levels of pollutants in soil, especially PTEs and certain organic contaminants which are commonly used as materials in electronic equipment (such as BDE-209). Several effects were observed after addition of the CD: firstly, a positive effect on fungal growth; secondly, a higher $\mathrm{Cd}$ accumulation in shoots and roots as a consequence of fungal growth increase, which increased roots and shoots biomass; and thirdly, an increased BDE-209 degradation efficiency. Only $5.5 \%$ of this contaminant was degraded in the unplanted soil. This percentage increased dramatically till $27 \%$ in cultivated soil, but was increased till 39\% after the addition of the fungus, and until 45\% when BCD at a percentage of $0.4 \%$ was incorporated. As it has been said previously, the amount of CD added is extremely important, and has to be taken into account in order not to increase the toxicity of the contaminant towards both the plant and fungus. When CD concentrations higher than $0.4 \%$ were used $(0.8 \%$ or $1.2 \%)$ the degradation efficiency of the organic pollutant decreased, and also diminished Cd uptake by the plant. These results indicated as a good bioremediation strategy to add $0.4 \%$ BCD together with mycorrhizal amaranth to cleanup sites co-contaminated with $\mathrm{Cd}$ and PBDEs. However, a previous study ( $\mathrm{Li}$ et al., 2018a) indicated that the combination of BCD and mycorrhizal Solanum nigrum significantly promoted the dissipation of BDE-209, but not difference in the removal of Cd was observed.

\section{Summary and Conclusions}

Summarizing all the information given above and that included in Tables 1-5, it can be observed that the most used CDs in soil bioremediation are the more soluble BCD derivatives HPBCD and RAMEB, due to their good water-solubility, biocompatibility, non-toxicity and moderate biodegradability, and also due to the fact that both derivatives 
are produced industrially, lowering their cost. The most universal BCD is the cheapest commercially available cyclodextrin, but it has a much lower water solubility for being used in bioremediation processes.

With respect to the pollutants treated in soils by CDs using bioremediation, almost $80 \%$ are industrial chemicals, and the rest are pesticides. It can be observed that, among industrial chemicals, PAHs are those mainly studied, giving about $36 \%$ of all the industrial chemicals bioremediated by CDs in soil. Further in descending order we have to mention PCBs, diesel and transformer oils, and alkanes and phenols, with considerably less percentages. Among the pesticides treated with CDs for their bioremediation in soils, it is observed that are included those which appear more frequently in scientific publications (diuron, chlorpirifos, diazinon) and also those proposed as POPs by the Stockholm Convention, whose use is banned, such as DDT and its metabolites, hexachlorocyclohexane (HCH), pentachlorophenols (PCP), chlordane or Endosulfan.

In relation to an economic analysis, there is a lack of information and objective evaluation of in situ technologies regarding soil bioremediation with CDs because the bioremediation processes for different contaminants that have been proved to be successful in laboratory scale test need to be scaled up to be able to calculate their real cost. As far as we know there is only one exhaustive economic analysis carried out by Gruiz et al. $(2009,2010)$ in the frame of the MOKKA project previously described to evaluate the cost-efficiency of the $\mathrm{CD}$ technology in comparison to other technological alternatives. The price of the CDs is frequently argued for not selecting them as remediation technology, but they demonstrated that the cost-efficiency was similar or even lower than in other technologies, proving their efficiency and competitiveness.

Also, as a conclusion of all the information given here, the strengths and weaknesses of the use of CDs for soil bioremediation have been observed. As strengths we can mention several: (I) CDs increase the bioavailability of poorly bioavailable contaminants and can accelerate their biodegradation in soil. (II) CD-bioremediation technology is applicable in situ and no soil removal and transport is necessary. (III) It is a bioremediation technology based on the use of native soil microflora and plants. (IV) CDs are environmentally friendly and soil quality is not negatively affected. (V) The addition of CDs and nutrients added can be controlled. (VI) CDs are moderately biodegradable natural compound. The biodegradation half-life for some of them up to 1.5 years is comparable with the duration of the technology. After fulfilling its role, they disappear 
from the soil. (VII) CDs can be used for various families of organic contaminants. (VIII) CDs technology is less time-consuming than other alternative technologies; the time requirement can be reduced to $40-70 \%$ with respect to other normally used remediation technologies. The decreased treatment time results in more rapid utilization of the site and more benefits from future land use.

In relation to the weaknesses of this technology which should be overcome they can be mention the following: (I) The price of the CDs normally used in soil bioremediation, such as HPBCD or RAMEB, is still relatively high in comparison to synthetic surfactants. And probably this is the main cause for the rest of weaknesses and for the scarce use of this remediation technology in spite of its good results at laboratory scale. (II) Thus, for example, there are very few good references for field application of CDs for bioremediation in the world, and the CDs remediation technology is not well-known and has not yet entered the market. (III) As a consequence, the knowledge about the effect of this technology on the soil ecosystem is only limited.

Therefore, for the future it would be desirable to achieve decreasing prices for the CDs more applied for biodegradation. In this way, their application can become widespread. Also a better knowledge about the cost-benefit relation of this technology would be desirable to demonstrate the advantages of their use. And a widespread application of CDs to new organic contaminants families (some emergent contaminants) which has not been tested yet would be also desirable. And finally, we hope that the increasingly more and more restrictive conditions imposed by the EU and other international statements for the development of clean technologies in soil remediation (Breure et al., 2018) give as a result an increased use of CDs as environmentally friendly agents for this purpose.

\section{Acknowledgements}

This work was supported by the Spanish Ministry of Science, Innovation and Universities under the research project CTM2017-82472-C2-1-R (AEI/FEDER, UE). A. AlbaMoreno acknowledges the Spanish Ministry of Education, Culture and Sports for her FPU fellowship (FPU15/03740). 


\section{Appendix A}

Table A.1. List of abbreviations used in the manuscript.

\begin{tabular}{|c|c|}
\hline AMF & Arbuscular Mycorrhizal fungus \\
\hline AOPs & Advanced oxidation processes \\
\hline $\mathrm{ACD}$ & $\alpha$-cyclodextrin \\
\hline $\mathrm{BCD}$ & $\beta$-cyclodextrin \\
\hline BDE-209 & Decabromodiphenyl ether \\
\hline $\mathrm{BS}$ & Biosurfactant \\
\hline BTEX & benzene, toluene, ethylbenzene and xylene \\
\hline $\mathrm{CD}$ & Cyclodextrin \\
\hline CMBCD & Carboxymethyl- $\beta$-cyclodextrin \\
\hline DDT & Dichloro diphenyl trichloroethane \\
\hline EK & Electrokinetic process \\
\hline FLT & Fluoranthene \\
\hline GCD & $\gamma$-cyclodextrin \\
\hline HPBCD & Hydroxypropyl- $\beta$-cyclodextrin \\
\hline HPGCD & Hydroxypropyl- $\gamma$-cyclodextrin \\
\hline HPLC & High performance liquid chromatography \\
\hline HS & Humic substances \\
\hline MBCD & methyl- $\beta$-cyclodextrin \\
\hline NP & Nonylphenol \\
\hline NPEs & Nonylphenol ethoxilates \\
\hline $\mathrm{OM}$ & Organic matter \\
\hline PAHs & Polycyclic Aromatic Hydrocarbons \\
\hline PBDEs & polybrominated diphenyl ethers \\
\hline PCBs & Polychloride biphenyls \\
\hline PCDDs & Polychlorinated dibenzodioxins \\
\hline PCDFs & Polychlorinated dibenzofurans \\
\hline PFAS & Perfluoroalkyl substances \\
\hline POPs & Persistent Organic Pollutants \\
\hline PTEs & Potentially Toxic Elements \\
\hline PYR & Pyrene \\
\hline $\mathrm{RL}$ & Rhamnolipid \\
\hline RAMEB & Randomly methylated- $\beta$-cyclodextrin \\
\hline TCE & Trichloroethylene \\
\hline WWTP & Wastewater treatment plant \\
\hline
\end{tabular}




\section{REFERENCES}

Aioub, A.A.A., Li, Y., Qie, X., Zhang, X., Hu. Z., 2019. Reduction of soil contamination by cypermethrin residues using phytoremediation with Plantago major and some surfactants. Environ. Sci. Eur. 31, 26. DOI: 10.1186/s12302-019-0210-4.

Allan, I.J., Semple, K.T., Hare, R., Reid, B.J., 2006. Prediction of mono-and polycyclic aromatic hydrocarbon degradation in spiked soils using cyclodextrin extraction. Environ. Pollut. 44, 562-571. DOI: 10.1016/j.envpol.2006.01.026.

Allan, I.J., Semple, K.T., Hare, R., Reid, B.J., 2007. Cyclodextrin enhanced biodegradation of polycyclic aromatic hydrocarbons and phenols in contaminated soil slurries. Environ. Sci. Technol. 41, 5498-5504. DOI: 10.1021/es0704939.

Badr, T., Hanna, K., de Brauer, C., 2004. Enhanced solubilization and removal of naphthalene and phenanthrene by cyclodextrins from two contaminated soils. J. Hazard. Mat. 112, 215-223. DOI: 10.1016/j.jhazmat.2004.04.017.

Báez, M.E., Espinoza, J., Silva, R., Fuentes, E. 2017. Influence of selected cyclodextrins in sorption-desorption of chlorpyrifos, chlorothalonil, diazinon, and their main degradation products on different soils. Environ. Sci. Pollut. Res. 24, 20908-20921. DOI: $10.1007 / \mathrm{s} 11356-017-9652-7$.

Báez, M.E., Espinoza, J., Fuentes, E., 2018. Degradation kinetics of chlorpyrifos and diazinon in volcanic and non-volcanic soils: influence of cyclodextrins. Environ. Sci. Pollut. Res. 25, 25020-25035. DOI: 10.1007/s11356-018-2559-0.

Balogh, K., Szaniszlo, N., Otta, K.H., Fenyvesi, E., 2007. Can cyclodextrins really improve the selectivity of extraction of BTEX compounds? J. Inclusion Phenom. Macrocyclic Chem. 57: 457-462. DOI: 10.1007/s10847-006-9234-7.

Bardi, L., Ricci, R., Marzona, M., 2003. In situ bioremediation of a hydrocarbon polluted site with cyclodextrin as a coadjuvant to increase bioavailability. Water, Air, Soil Pollut. Focus, 3, 15-23, 2003. DOI: 10.1023/A:1023946205178.

Bardi, L., Martini, C., Opsi, F., Bertolone, E., Belviso, S., Masoero, G., Marzona, M., Ajmone- Marsan, F., 2007. Cyclodextrin-enhanced in situ bioremediation of polyaromatic hydrocarbons-contaminated soils and plant uptake. J. Inclusion Phenom. Macrocyclic Chem. 57, 439-444. DOI: 10.1007/s10847-006-9231-x.

Bergknut, M., Sehlin, E., Lundstedt, S., Andersson, P.L., Haglund, P., Tysklind, M., 2007. Comparison of techniques for estimating PAH bioavailability: Uptake in Eisenia fetida, passive samplers and leaching using various solvents and additives. Environ. Pollut. 145, 154-160. DOI: 10.1016/j.envpol.2006.03.052.

Blanford, W.J., Pecoraro, M.P., Heinrichs, R., Boving, T.B. 2018. Enhanced reductive de-chlorination of a solvent contaminated aquifer through addition and apparent fermentation of cyclodextrin. Journal of Contaminant Hydrology 208, 68-78. DOI: 10.1016/j.jconhyd.2017.10.006.

Breure, A.M.; Lijzen, J.P.A., Maring, L., 2018. Soil and land management in a circular economy. Sci. Total Environ. 624, 1025-1030. DOI: 10.1016/j.scitotenv.2017.12.137.

Boving, T.B., Blanford, W.J., McCray, J.E., Divine, C.E., Brusseau, M.L. 2008. Comparison of line-drive and push-pull flushing schemes. Ground Water Monitoring and Remediation 28, 75-86. DOI: 10.1111/j.1745-6592.2007.00182.x. 
Chen, F., Yang, B., Ma, J., Qu, J., Liu, G., 2016a. Decontamination of electronic wastepolluted soil by ultrasound-assisted soil washing. Environ. Sci. Pollut. Res. 23, 2033120340. DOI: 10.1007/s11356-016-7271-3.

Chen, F., Tan, M., Ma, J., Zhang, S.L., Li, G., Qu, J.F., 2016b. Efficient remediation of PAH-metal co-contaminated soil using microbial-plant combination: a greenhouse study. J. Hazard Mater. 302, 250-261. DOI: 10.1016/j.jhazmat.2015.09.068.

Chen, F., Luo, Z., Liu, G., Yang, Y., Zhang, S., Ma, J., 2017. Remediation of electronic waste polluted soil using a combination of persulfate oxidation and chemical washing. J. Environ. Manag. 204, 170-178. DOI: 10.1016/j.jenvman.2017.08.050.

Chen, F., Li, X., Ma, J., Qu, J., Yang, Y., Zhang, S., 2019. Remediation of soil cocontaminated with decabromodiphenyl ether (BDE-209) and copper by enhanced electrokinetics-persulfate process. J. Hazard. Mat. 369, 448-455. DOI: 10.1016/j.jhazmat.2019.02.043.

Chen, Y., Tang, X., Cheema, S.A., Liu, W., Shen, C., 2010. $\beta$-cyclodextrin enhanced phytoremediation of aged PCBs-contaminated soil from e-waste recycling area. J. Environ. Monit. 12, 1482-1489. DOI: 10.1039/c0em00029a.

Crini, G. 2014. Review: A History of cyclodextrins. Chem. Rev. 114, 10940-10975. DOI: 10.1021/cr500081p.

Crini, G., Fourmentin, S., Fenyvesi, É., Torri, G., Fourmentin, M., Morin-Crini, N. 2018. Cyclodextrins, from molecules to applications. Environ. Chem. Lett. 16, 1361-1375. DOI: $10.1007 / \mathrm{s} 10311-018-0763-2$.

Cuypers, C., Pancras, T., Grotenhuis, T., 2002. The estimation of PAH bioavailability in contaminated sediments using hydroxypropyl-beta-cyclodextrin and Triton X-100 extraction techniques. Chemosphere 46, 1235-1245. DOI: 10.1016/S00456535(01)00199-0.

Dahmer, C.P., Rutter, A., Zeeb, B.A., 2018. The fate of DDT in soils treated with hydroxypropyl- $\beta$-cyclodextrin (HP $\beta C D)$. Int. J. Phytorem. 20, 523-529. DOI: 10.1080/15226514.2017.1393389.

Doick, K.J., Clasper, P.J., Urmann, K., Semple, K.T., 2006. Further validation of the HPCD-technique for the evaluation of PAH microbial availability in soil. Environ. Pollut. 144, 345-354. DOI: 10.1016/j.envpol.2005.10.054.

Dou, J., Li, S., Cheng, L., Ding, A., Liu, X., Yun, Y., 2011. The enhancement of naphthalene degradation in soil by hydroxypropyl- $\beta$-cyclodextrin. Procedia Environ. Sci. 10, 26-31. DOI: 10.1016/j.proenv.2011.09.006.

Ehsan, S., Prasher, S.O., Marshall, W.D., 2007. Simultaneous mobilization of heavy metals and polychlorinated biphenyl (PCB) compounds from soil with cyclodextrin and EDTA in admixture. Chemosphere 68, 150-158. DOI: 10.1016/j. chemosphere.2006.12.018.

El Fantroussi, S., Agathos, S.N. 2005. Is bioaugmentation a feasible strategy for pollutant removal and site remediation? Curr. Opinion Microbiol. 8, 268-275. DOI: 10.1016/j.mib.2005.04.011.

Fava, F., Di Gioia, D., Marchetti, L., 1998. Cyclodextrin effects on the ex-situ bioremediation of a chronically polychlorobiphenyl-contaminated soil. Biotechnol. 
Bioeng. 58: $345-355$. DOI: $10.1002 /($ SICI) 1097-0290(19980520)58:4<345::AIDBIT1>3.0.CO;2-J.

Fava F., Ciccotosto V.F., 2002. Effects of randomly methylated- $\beta$-cyclodextrins (RAMEB) on the bioavailability and aerobic biodegradation of polychlorinated biphenyls in three pristine soils spiked with a transformer oil. Appl. Microbiol. Biotechnol. 58: 393399. DOI: 10.1007/s00253-001-0882-7.

Fava, F., Di Gioia, D., Marchetti, L., Fenyvesi, E., Szejtli, J., 2002. Randomly methylated $\beta$-cyclodextrins (RAMEB) enhance the aerobic biodegradation of polychlorinated biphenyl in aged-contaminated soils. J. Inclusion Phenom. Macrocyclic Chem. 44, 417421. DOI: $10.1023 / \mathrm{A}: 1023019903194$.

Fava, F., Bertin, L., Fedi, S., Zannoni, D., 2003. Methyl- $\beta$-cyclodextrin-enhanced solubilization and aerobic biodegradation of polychlorinated biphenyls in two agedcontaminated soils. Biotechnol. Bioeng. 81, 381-390. DOI: 10.1002/bit.10579.

Fedi, S., Tremaroli, V., Scala, D., Perez-Jimenez, J.R., Fava, F., Young, L., Zannoni, D., 2005. T-RFLP analysis of bacterial communities in cyclodextrin-amended bioreactors developed for biodegradation of polychlorinated biphenyls. Res. Microbiol. 156, 201210. DOI: 10.1016/j.resmic.2004.09.001.

Fenyvesi, E., Gruiz, K., Verstichel, S., DeWilde, B., Leitgib, L., Csabai, K., 2005. Biodegradation of cyclodextrins in soil. Chemosphere 60, 1001-1008. DOI: 10.1016/j.chemosphere.2005.01.026.

Fenyvesi, É., Molnár, M., Leitgib, L., Gruiz, K., 2009a. Cyclodextrin-enhanced soil remediation technologies. Land Contam. Reclam. 17, 585-597. DOI: 10.2462/09670513.977.

Fenyvesi, É., Leitgib, L., Gruiz, K., Balogh, G., Murányi, A., 2009b. Demonstration of soil bioremediation technology enhanced by cyclodextrin. Land Contam. Reclam., 17, 611-617. DOI: 10.2462/09670513.977.

Fenyvesi, É., Csabai, K., Molnár, M., Leitgi, L., Gruiz, K. 2010. Cyclodextrins for the enhancement of soil remediation technologies. In: Construction for a Sustainable Environment, Sarsby \& Meggyes (eds.) CRC Press, Taylor \& Francis Group, pp. 197206. ISBN 978-0-415-56617-9.

Fenyvesi, E., Balogh, K., Olah, E., Batai, B., Varga, E., Molnar, M., Gruiz, K., 2011. Cyclodextrins for remediation of soils contaminated with chlorinated organics. J Inclusion Phenom Macrocyclic Chem. 70, 291-297. DOI 10.1007/s10847-010-9839-8.

Fukushima, M., Tatsumi, K., 2007. Degradation of pentachlorophenol in contaminated soil suspensions by potassium monopersulfate catalyzed oxidation by a supramolecular complex between tetra(p-sulfophenyl)porphineiron(III) and hydroxypropyl-cyclodextrin. J. Hazard. Mat. 144, 222-228. DOI: 10.1016/j.jhazmat.2006.10.013.

Gao, H., Gao, X., Cao, Y., Xu, L., Jia, L., 2015. Influence of Hydroxypropyl- $\beta-$ cyclodextrin on the extraction and biodegradation of $\mathrm{p}, \mathrm{p}^{\prime}$-DDT, o, $\mathrm{p}^{\prime}$-DDT, $\mathrm{p}, \mathrm{p}^{\prime}-\mathrm{DDD}$, and p,p'-DDE in soils. Water Air Soil Pollut. 226, 208. DOI 10.1007/s11270-015-2472-9.

Garon, D., Sage, L., Wouessidjewe, D., Seigle-Murandi, F., 2004. Enhanced degradation of fluorene in soil slurry by Absidia cylindrospora and maltosyl-cyclodextrin. Chemosphere 56, 159-166. DOI: 10.1016/j.chemosphere.2004.02.019. 
Gerhardt, K.E., Huang, X.D., Glick, B.R., Greenberg, B.M., 2009. Phytoremediation and rhizoremediation of organic soil contaminants: Potential and challenges. Plant Sci. 176, 20-30. DOI:10.1016/j.plantsci.2008.09.014.

Ginés, J.M., Pérez-Martinez, J.I., Arias, M.J., Moyano, J.R., Morillo, E., Ruiz-Conde, A., Sánchez-Soto, P.J. 1996. Inclusion of the herbicide 2,4-dichlorophenoxyacetic acid (2,4D) with $\beta$-cyclodextrin by different processing methods. Chemosphere 33, 321-334. DOI: $10.1016 / 0045-6535(96) 00175-0$.

Gomes, H., Dias-Ferreira, C., Ribeiro, A.B. 2013. Overview of in situ and ex situ remediation technologies for PCB-contaminated soils and sediments and obstacles for full-scale application. Sci. Total Environ. 445-446C, 237-260. DOI: 10.1016/j.scitotenv.2012.11.098.

Gruiz, K., Fenyvesi, É., Kriston, É., Molnár, M., Horváth, B., 1996. Potential use of cyclodextrins in soil bioremediation. J. Inclusion Phenom. Macrocyclic Chem. 25, 233236. DOI: 10.1007/BF01041576.

Gruiz, K., Molnár, M., Fenyvesi, E., 2007. Evaluation and verification of soil remediation. In: Environmental Microbiology Research Trends. G.V. Kurladze (ed.) Nova Science Publishers, Inc. pp. 1-57. ISBN: 978-1-60021-939-9.

Gruiz, K., Molnár, M., Fenyvesi, E., 2009. Verification tool for in situ soil remediation. Land Contam. Reclam. 17, 339-362. DOI: 10.2462/09670513.982.

Gruiz, K., Molnár, M., Fenyvesi, E., 2010. Multistage verification of soil remediation. In: Construction for a Sustainable Environment, Sarsby \& Meggyes (eds.) CRC Press, Taylor \& Francis Group, pp. 207-218. ISBN 978-0-415-56617-9.

Gruiz, K., 2019. Natural attenuation in contaminated soil remediation. In: Engineering Tools for Environmental Risk Management: 4. Risk Reduction Technologies and Case Studies. K. Gruiz, T. Meggyes, É. Fenyvesi (eds.). CRC Press, Taylor \& Francis Group, pp. 95-201. ISBN: 978-1-138-00157-2 (Hardback), 978-1-315-77875-4 (eBook).

Hajdu C., Gruiz K., Fenyvesi E., Nagy Z.M., 2011. Application of cyclodextrins in environmental bioassays for soil. J. Inclusion Phenom. Macrocyclic Chem. 70, 307-313. DOI 10.1007/s10847-010-9855-8.

Hanna, K., Chiron, S., Oturan, M.A., 2005. Coupling enhanced water solubilization with cyclodextrin to indirect electrochemical treatment for pentachlorophenol contaminated soil remediation. Water Res. 39, 2763-2773. DOI: 10.1016/j.watres.2005.04.057.

Hartnik, T., Jensen, J., Hermens, J.L.M., 2008. Nonexhaustive $\beta$-cyclodextrin extraction as a chemical tool to estimate bioavailability of hydrophobic pesticides for earthworms. Environ. Sci. Technol. 42, 8419-8425. DOI: 10.1021/es8008908.

Hoffman, D.R., Anderson, P.P., Schubert, C.M., Gault, M.B., Blanford, W.J., Sandrin, T.R., 2010 Carboxymethyl-beta-cyclodextrin mitigates toxicity of cadmium, cobalt, and copper during naphthalene biodegradation. Bioresour Technol. 101, 2672-2677. DOI: 10.1016/j.biortech.2009.10.073.

Hu, J., Wang, Y., Su, X., Yu, C., Qin, Z., Wang, H., Hashmi, M.Z., Shi, J., Shen, C., 2016. Effects of RAMEB and/or mechanical mixing on the bioavailability and biodegradation of PCBs in soil/slurry. Chemosphere 155, 479-487. DOI: 10.1016/j.chemosphere.2016.04.084. 
Huang, H.G., Ning, Y., Wang, L.J., Gupta, D.K., He, Z.L., Kai, W., Zhu, Z.Q., Yan, X.C., Li, T.Q., Yang, X.E., 2011. The phytoremediation potential of bioenergy crop Ricinus communis for DDTs and cadmium co-contaminated soil. Bioresour. Technol. 102, 11034-11038. DOI: 10.1016/j.biortech.2011.09.067.

Jozefaciuk, G., Muranyi, A., Fenyvesi, E., 2001. Effect of cyclodextrins on surface and pore properties of soil clay minerals. Environ. Sci. Technol. 35, 4947-4952. DOI: $10.1021 /$ es010083z.

Jozefaciuk, G., Muranyi, A., Fenyvesi, E., 2003. Effect of randomly methylated $\beta$ cyclodextrin on physical properties of soils. Environ. Sci. Technol. 37, 3012-3017. DOI: $10.1021 / \mathrm{es} 026236 \mathrm{f}$.

Kastner, M., Nowak, K.M., Miltner, A., Trapp, S., Schaffer, A., 2014. Classification and modelling of nonextractable residue (NER) formation of xenobiotics in soil - A synthesis. Crit. Rev. Environ. Sci. Technol. 44, 2107-2171. DOI: 10.1080/10643389.2013.828270.

Kaur, P., Kaur, P., 2020. $\beta$-Cyclodextrin-chitosan biocomposites for synergistic removal of imazethapyr and imazamox from soils: Fabrication, performance and mechanisms. Sci. Total Environ. 710, 135659. DOI: 10.1016/j.scitotenv.2019.135659.

Kong, F.X., Sun, G.D., Liu, Z.P., 2018. Degradation of polycyclic aromatic hydrocarbons in soil mesocosms by microbial/plant bioaugmentation: performance and mechanism. Chemosphere 198, 83-91. DOI: 10.1016/j.chemosphere.2018.01.097.

Landy, D., Mallard, I., Ponchel, A., Monflier, E., Fourmentin, S., 2012. Remediation technologies using cyclodextrins: an overview. Environ. Chem. Lett. 10, 225-237. DOI 10.1007/s10311-011-0351-1.

Leech, C., Tighe, M.K., Pereg, L., Winter, G., McMillan, M., Esmaeili, A., Wilson, S.C., 2020. Bioaccessibility constrains the co-composting bioremediation of field aged PAH contaminated soils. Int. Biodet. Biodeg. 149, art. no. 104922. DOI: 10.1016/j.ibiod.2020.104922.

Leitgib, L., Gruiz, K., Molnár, M., Fenyvesi, É., 2003. Bioremediation of transformer oil contaminated soil. In: Annokkée, G.J., Arendt, F., Uhlmann, O., (eds), Wissenschaftliche Berichte, FZKA 6943, Karlsruhe, pp. 2762-2771.

Leitgib, L., Gruiz, K., Fenyvesi, É., Balogh, G., Murányi, A., 2008. Development of an innovative soil remediation: "Cyclodextrin-enhanced combined technology". Sci. Total Environ., 392, 12-21. DOI: 10.1016/j.scitotenv.2007.10.055.

Lemaire, J., Mora, V., Faure, P., Hanna, K., Buès, M., Simonnot, M.O., 2019. Chemical oxidation efficiency for aged, PAH-contaminated sites: An investigation of limiting factors. J. Environ. Chem. Eng. 7, 103061. DOI: 10.1016/j.jece.2019.103061.

Leonardi, V., Giubilei, M.A., Federici, E., Spaccapelo, R., Sasek, V., Novotny, C., Petruccioli, M., D'Annibale, A., 2008. Mobilizing agents enhance fungal degradation of polycyclic aromatic hydrocarbons and affect diversity of indigenous bacteria in soil. Biotech. Bioeng. 101, 273-285. DOI: 10.1002/bit.21909.

Li, H., Li, X., Xiang, L., Zhao, H.M., Li, Y.W., Cai, Q.Y., Zhu, L., Mo, C.H., Wong, M.H., 2018a. Phytoremediation of soil co-contaminated with Cd and BDE-209 using hyperaccumulator enhanced by AM fungi and surfactant. Sci. Total Environ. 613-614, 447-455. DOI: 10.1016/j.scitotenv.2017.09.066. 
Li, X., Chen, A.Y., Wu, Y., Wua, L., Xiang, L., Zhao, H.M., Cai, Q.Y., Li, Y.W., Mo, C.H., Wong, M.H., Li, H. 2018b. Applying $\beta$-cyclodextrin to amaranth inoculated with white-rot fungus for more efficient remediation of soil co-contaminated with $\mathrm{Cd}$ and BDE-209. Sci. Total Environ. 634, 417-426. DOI: 10.1016/j.scitotenv.2018.03.310.

Li, X., Chen, A.Y., Yu, L.Y., Chen, X.X., Xiang, L., Zhao, H.M., Mo, C.H., Li, Y.W., Cai, Q.Y., Wong, M.H., Li, H., 2019. Effects of $\beta$-cyclodextrin on phytoremediation of soil co-contaminated with $\mathrm{Cd}$ and BDE-209 by arbuscular mycorrhizal amaranth. Chemosphere 220, 910-920. DOI: 10.1016/j.chemosphere.2018.12.211.

Ling, Y., Alzate-Sánchez, D.M., Klemes, M.J., Dichtel, W.R., Helbling, D.E. 2020. Evaluating the effects of water matrix constituents on micropollutant removal by activated carbon and $\beta$-cyclodextrin polymer adsorbents. Water Res. 173, 115551. DOI: 10.1016/j.watres.2020.115551.

Liu, L., Guo, Q.X. 2002. The driving forces in the inclusion complexation of cyclodextrins. J. Incl. Phenom. 42, 1-14. DOI: 10.1023/A:1014520830813.

Liu T., Ding K., Guo G., Yang F., Wang L., 2018. Effects of hydroxypropyl- $\beta$ cyclodextrin on pyrene and benzo[ $\alpha]$ pyrene: bioavailability and degradation in soil. Chem. Ecol., 34, 519-531. DOI: 10.1080/02757540.2018.1462343.

Lu, Z., Gan, J., 2014. Analysis, toxicity, occurrence and biodegradation of nonylphenol isomers: A review. Environ. Int. 73, 334-345. DOI: 10.1016/j.envint.2014.08.017.

Luo, W., D’Angelo, E.M., Coyne, M.S., 2007. Plant secondary metabolites, biphenyl, and hydroxypropyl- $\beta$-cyclodextrin effects on aerobic polychlorinated biphenyl removal and microbial community structure in soils. Soil Biol. Biochem. 39, 735-743. DOI: 10.1016/j.soilbio.2006.09.019.

Madrid, F., Rubio-Bellido, M., Villaverde, J., Tejada, M., Morillo, E., 2016. Natural attenuation of fluorene and pyrene in contaminated soils and assisted with hydroxypropyl- $\beta$-cyclodextrin. Effect of co-contamination. Sci. Total Environ. 571, 4249. DOI: 10.1016/j.scitotenv.2016.07.110.

Madrid, F., Rubio-Bellido, M., Villaverde, J., Peña, A., Morillo, E., 2019a. Natural and assisted dissipation of polycyclic aromatic hydrocarbons in a long-term co-contaminated soil with creosote and potentially toxic elements. Sci. Total Environ. 660, 705-714. DOI: 10.1016/j.scitotenv.2018.12.376.

Madrid, F., Ballesteros, R., Lacorte, S., Villaverde, J., Morillo, E., 2019b. Extraction of PAHs from an aged creosote-polluted soil by cyclodextrins and rhamnolipids. Side effects on removal and availability of potentially toxic elements. Sci. Total Environ. 653, 384 392. DOI: $10.1016 /$ j.scitotenv.2018.10.316.

Mahmoudi, N., Slater, G.F., Juhasz, A.L. 2013. Assessing Limitations for PAH Biodegradation in Long-Term Contaminated Soils Using Bioaccessibility Assays. Water Air Soil Pollut. 224, 1411. DOI 10.1007/s11270-012-1411-2.

Mallard, I., Städe, L.W., Ruellan, S., Jacobsen, P.A.L., Larsen, K.L., Fourmentin, S. 2015. Synthesis, characterization and sorption capacities toward organic pollutants of new $\beta$-cyclodextrin modified zeolite derivatives. Colloids Surf. A Physicochem. Eng. Asp. 482, 50-57. DOI: 10.1016/j.colsurfa.2015.04.014. 
Martín del Valle, E.M., 2004. Cyclodextrins and their uses: A review. Process Biochem. 39, 1033-1046. DOI: 10.1016/S0032-9592(03)00258-9.

Martínez-Bravo M., Martínez-del-Río J. 2019. Urban Pollution and Emission Reduction. In: Leal Filho W., Azul A., Brandli L., Özuyar P., Wall T. (eds) Sustainable cities and communities. Encyclopedia of the UN sustainable development goals. Springer, Cham. DOI: 10.1007/978-3-319-71061-7. ISBN: 978-3-319-71061-7.

Megharaj, M., Ramakrishnan, B., Venkateswarlu, K., Sethunathan, N., Naidu, R. 2011. Bioremediation approaches for organic pollutants: A critical perspective. Environ. Int. 37, 1362-1375. DOI: 10.1016/j.envint.2011.06.003.

Molnár, M., Fenyvesi, É., Gruiz, K., Leitgib, L., Balogh, G., Murányi, A. and Szejtli, J., 2002. Effects of RAMEB on bioremediation of different soils contaminated with hydrocarbons. J. Inclus. Phenom. Macrocyclic Chem. 44, 447-452. DOI: 10.1023/A:1023032305920.

Molnár, M., Leitgib, L., Gruiz, K., Fenyvesi, É., Szaniszló, N., Szejtli, J. and Fava, F. (2005) Enhanced biodegradation of transformer oil in soils with cyclodextrin - from the laboratory to the field. Biodegrad. 16, 159-168. DOI: 10.1007/s 10532-004-4873-0.

Molnar, M., Leitgib, L., Fenyvesi, E., Gruiz, K., 2009. Development of cyclodextrinenhanced soil remediation: from the laboratory to the field. Land Contam. Reclam. 17, 599-610. DOI: 10.2462/09670513.976.

Molnar, M., Gruiz, K., Fenyvesi, E., 2019. Biodegradation-based remediation. Overview and case studies. In: Engineering Tools for Environmental Risk Management: 4. Risk Reduction Technologies and Case Studies. Gruiz, K., Meggyes, T., Fenyvesi, É. (eds.). pp. 243-275. CRC Press, Taylor \& Francis Group. ISBN: 978-1-138-00157-2 (Hardback), 978-1-315-77875-4 (eBook).

Morillo, E., Pérez-Martínez, J.I., Ginés, J.M. (2001) Leaching of 2,4-D from a soil in the presence of $\beta$-cyclodextrin: laboratory columns experiments. Chemosphere 44, 1065 1069. DOI: $10.1016 / \mathrm{S} 0045-6535(00) 00346-5$.

Morillo, E., Sanchez-Trujillo, M.A., Moyano, J.R., Villaverde, J., Gomez-Pantoja, M.E., Perez-Martinez, J.I., 2012. Enhanced solubilization of six PAHs by three synthetic cyclodextrins for remediation applications: molecular modeling of the inclusion complexes. PLoS ONE 7, e44137. DOI: 10.1371/journal.pone.0044137.

Morillo, E., Sánchez-Trujillo, M.A., Villaverde, J., Madrid, F., Undabeytia, T., 2014. Effect of contact time and the use of hydroxypropyl- $\beta$-cyclodextrin in the removal of fluorene and fluoranthene from contaminated soils. Sci. Total Environ. 496, 144-154. DOI: $10.1016 /$ j.scitotenv.2014.07.027

Morillo, E., Villaverde, J., 2017. Advanced technologies for the remediation of pesticidecontaminated soils. Sci. Total Environ. 586, 576-597. DOI: 10.1016/j.scitotenv.2017.02.020.

Mousset, E., Oturan, M.A., Van Hullebusch, E.D., Guibaud, G., Esposito, G., 2014a. Soil washing/flushing treatments of organic pollutants enhanced by cyclodextrins and integrated treatments: State of the Art. Crit. Rev. Environ. Sci. Technol., 44, 705-795. DOI: $10.1080 / 10643389.2012 .741307$. 
Mousset E., Oturan N., vanHullebusch E.D., Guibaud G., Esposito G., Oturan M.A., 2014b. Treatment of synthetic soil washing solutions containing phenanthrene and cyclodextrin by electro-oxidation. Influence of anode materials on toxicity removal and biodegradability enhancement. Appl. Catalysis B: Environ. 160-161, 666-675. DOI: 10.1016/j.apcatb.2014.06.018.

Mouton, J., Mercier, G., Drogui, P., Blais, J.F., 2009. Experimental assessment of an innovative process for simultaneous $\mathrm{PAHs}$ and $\mathrm{Pb}$ removal from polluted soils. Sci. Total Environ. 407, 5402-5410. DOI: 10.1016/j.scitotenv.2009.06.042.

Nagy, Z.M., Gruiz, K., Molnár, M., Fenyvesi, É., 2013. Comparative evaluation of microbial and chemical methods for assessing 4-chlorophenol biodegradation in soil. Chem. Eng. 57, 25-35. DOI: 10.3311/PPch.2167.

Papadopoulos, A., Paton, G.I., Reid, B.J., 2007. Prediction of PAH biodegradation in field contaminated soils using a cyclodextrin extraction technique. J. Environ. Monit. 9, 516522. DOI: 10.1039/b700720e.

Pérez-Martínez, J.I., Morillo, E., Ginés, J.M. 1999. $\beta$-CD effect on 2,4-D soil adsorption. Chemosphere 39, 2047-2056. DOI: 10.1016/S0045-6535(99)00093-4.

Petitgirard A., Djehiche M., Persello J., Fievet P., Fatin-Rouge N., 2009. PAH contaminated soil remediation by reusing an aqueous solution of cyclodextrins. Chemosphere 75, 714-718. DOI: 10.1016/j.chemosphere.2009.01.072.

Prochowicz, D., Kornowicz, A., Justyniak, I., Lewiński, J., 2016. Metal complexes based on native cyclodextrins: Synthesis and structural diversity. Coord. Chem. Rev. 306, 331345. DOI: 10.1016/j.ccr.2015.07.016.

Qin, H., Brookes, P.C., Xu, J.M., 2016. Arbuscular mycorrhizal fungal hyphae alter soil bacterial community and enhance polychlorinated biphenyls dissipation. Front. Microbiol. 7, 1-10. DOI: 10.3389/fmicb.2016.00939.

Ramsay, J.A., Robertson, K., vanLoon, G., Acay, N., Ramsay, B.A., 2005. Enhancement of PAH biomineralization rates by cyclodextrins under Fe(III)-reducing conditions. Chemosphere 61, 733-740. DOI: 10.1016/j.chemosphere.2005.03.060.

Rekharsky, M.V., Inoue, Y. 1998. Complexation thermodynamics of cyclodextrins. Chem. Rev. 98, 1875-1917.

Reid, B.J., Stokes, J.D., Jones, K.C., Semple, K.T. 2000. Nonexhaustive cyclodextrinbased extraction technique for the evaluation of PAH bioavailability. Environ. Sci. Technol. 34, 3174-3179. DOI: 10.1021/es990946c.

Reid, B.J., Stokes, J.D., Jones, K.C., Semple, K.T. 2004. Influence of hydroxypropyl-bcyclodextrin on the extraction and biodegradation of phenanthrene in soil. Environ. Toxic. Chem. 23, 550-556. DOI: 10.1897/02-567.

Ren, B., Zhang, M., Gao, H., Zheng, J., Jia, L. Atomic elucidation of the cyclodextrin effects on DDT solubility and biodegradation. Phys. Chem. Chem. Phys. 18, 1738017388. DOI: $10.1039 / \mathrm{c} 6 \mathrm{cp} 02790 \mathrm{c}$.

Rhodes, A.H., Dew, N.M., Semple, K.T., 2008. Relationship between cyclodextrin extraction and biodegradation of phenanthrene in soil. Environ. Toxic. Chem. 27, 14881495. DOI: 10.1897/07-363.1. 
Romeh A.A., 2015. Enhancing agents for phytoremediation of soil contaminated by cyanophos. Ecotoxicol. Environ. Saf. 117, 124-131. DOI: 10.1016/j.ecoenv.2015.03.029.

Rubio-Bellido, M., Madrid, F., Morillo, E., Villaverde, J., 2015. Assisted attenuation of a soil contaminated by diuron using hydroxypropyl- $\beta$-cyclodextrin and organic amendments. Sci. Total Environ. 502, 699-705. DOI: 10.1016/j.scitotenv.2014.09.052.

Rubio-Bellido, M., Morillo, E., Villaverde, J., 2016. Effect of addition of HPBCD on diuron adsorption-desorption, transport and mineralization in soils with different properties. Geoderma 265, 196-203. DOI: 10.1016/j.geoderma.2015.11.022.

Rubio-Bellido M., Morillo E., Villaverde J., 2018. Assessment of soil diuron bioavailability to plants and microorganisms through non-exhaustive chemical extractions of the herbicide. Geoderma 312, 130-138. DOI: 10.1016/j.geoderma.2017.09.031.

Sabaté, J., Viñas, M., Solanas, A.M., 2006. Bioavailability assessment and environmental fate of polycyclic aromatic hydrocarbons in biostimulated creosote-contaminated soil. Chemosphere 63, 1648-1659. DOI: 10.1016/j.chemosphere.2005.10.020.

Sánchez-Trujillo, M.A., Morillo, E., Villaverde, J., Lacorte, S., 2013. Comparative effects of several cyclodextrins on the extraction of PAHs from an aged contaminated soil. Environ. Pollut. 178, 52-58. DOI: 10.1016/j.envpol.2013.02.029.

Saxena, G., Bharagava, R.N. 2017. Organic and inorganic pollutants in industrial wastes: Ecotoxicological effects, health hazards, and bioremediation approaches. In: Bharagava (ed.) Environmental Pollutants and their Bioremediation Approaches, pp. 23-56. CRC Press. ISBN: 978-135170059-7;978-113862889-2. DOI: 10.1201/b22171.

Semple, K.T., Doick, K.J., Jones, K.C., Burauel, P., Craven, A., Harms, H., 2004. Defining bioavailability and bioaccessibility of contaminated soil and sediment is complicated. Environ. Sci. Technol. 38, 228A-231A. DOI: 10.1021/es040548w.

Shen, C., Tang, X., Cheema, S.A., Zhang, C., Khana, M.I., Liang, F., Chen, X., Zhu, Y., Lin, Q., Chen, Y., 2009. Enhanced phytoremediation potential of polychlorinated biphenyl contaminated soil from e-waste recycling area in the presence of randomly methylated- $\beta$-cyclodextrins. J. Hazard. Mat. 172, 1671-1676. DOI: 10.1016/j.jhazmat.2009.08.064.

Simpanen, S., Makela, R., Mikola, J., Silvennoinen, H., Romantschuk, M., 2016. Bioremediation of creosote contaminated soil in both laboratory and field scale: Investigating the ability of methyl- $\beta$-cyclodextrin to enhance biostimulation. Int. Biodeterior. Biodegrad. 106, 117-126. DOI: 10.1016/j.ibiod.2015.10.013.

Skold, M.E., Thyne, G.D., Drexler, J.W., Macalady, D.L., McCray, J.E., 2008. Enhanced solubilization of a metal-organic contaminant mixture $(\mathrm{Pb}, \mathrm{Sr}, \mathrm{Zn}$, and perchloroethylene) by cyclodextrin. Environ. Sci. Technol. 42, 8930-8934. DOI: 10.1021/es801835x.

Skold, M.E., Thyne, G.D., Drexler, J.W., McCray, J.E., 2009. Solubility enhancement of seven metal contaminants using carboxymethyl- $\beta$-cyclodextrin (CMCD). J. Contam. Hydrol. 107, 108-113. DOI: 10.1016/j.jconhyd.2009.04.006.

Snow, D.D., Cassada, D.A., Larsen, M.L., Mware, N.A., Li, X., D’Alessio, M., Zhang, Y., Sallach, J. B., 2017. Detection, Occurrence and Fate of Emerging Contaminants in 
Agricultural Environments. Water Environ. Res. 89, 897-920. DOI:10.2175/106143017X15023776270160.

Sopeña, F., Laiz, L., Morillo, E., Sanchez-Trujillo, M.A., Villaverde, J., Jurado, V., SaizJimenez, C. 2014. Phenanthrene biodegradation by Pseudomonas xanthomarina isolated from an aged contaminated soil. Clean - Soil Air Water 42, 785-790. DOI: 10.1002/clen.201300247.

Stockholm Convention on Persistent Organic Contaminants (POPs). 2011. The New POPs under the Stockholm Convention. Available at http://chm.pops.int/TheConvention/ThePOPs/ TheNewPOPs/tabid/2511/Default.aspx.

Stokes, J.D., Wilkinson, A., Reid, B.J., Jones, K.C., Semple, K.T., 2005. Prediction of PAH biodegradation in contaminated soils using an aqueous hydroxypropylbetacyclodextrin extraction technique. Environ. Toxicol. Chem. 24, 1325-1330. DOI: 10.1897/04-336R.1.

Stroud J.L., Paton G.I., Semple K.T., 2009a. Predicting the biodegradation of target hydrocarbons in the presence of mixed contaminants in soil. Chemosphere 74, 563-567. DOI: 10.1016/j.chemosphere.2008.09.071.

Stroud J.L., Tzima M., Paton G.I., Semple K.T., 2009b. Influence of hydroxypropyl- $\beta$ cyclodextrin on the biodegradation of 14C-phenanthrene and 14C-hexadecane in soil. Environmental Pollution 157, 2678-2683. DOI: 10.1016/j.envpol.2009.05.009.

Sun, M., Luo, Y., Christie, P., Jia, Z., Li, Z., Teng, Y., 2012. Methyl- $\beta$-cyclodextrin enhanced biodegradation of polycyclic aromatic hydrocarbons and associated microbial activity in contaminated soil. J. Environ. Sci. 24(5) 926-933. DOI: 10.1016/S10010742(11)60865-6.

Sun, M., Luo, Y., Teng, Y., Jia, Z., Li, Z., Deng, S., 2013a. Remediation of polycyclic aromatic hydrocarbon and metal-contaminated soil by successive methyl- $\beta$-cyclodextrinenhanced soil washing-microbial augmentation: a laboratory evaluation. Environ. Sci. Pollut. Res. 20, 976-986. DOI: 10.1007/s11356-012-1064-0.

Sun, M., Luo, Y., Teng, Y., Christie, P., Jia, Z., Li, Z., 2013b. Tenax TA extraction to understand the rate-limiting factors in methyl-b-cyclodextrin-enhanced bioremediation of PAH-contaminated soil. Biodegrad. 24, 365-375. DOI: 10.1007/s10532-012-9593-2.

Sun, M., Ye, M., Hu, F., Li, H., Teng, Y., Luo, Y., Jiang, X., Kengara, F.O., 2014. Tenax extraction for exploring rate-limiting factors in methyl- $\beta$-cyclodextrin enhanced anaerobic biodegradation of PAHs under denitrifying conditions in a red paddy soil. J. Hazard. Mat. 264, 505- 513. DOI: 10.1016/j.jhazmat.2013.10.032.

Szejtli, J. 1984. Limits of cyclodextrin application in oral drug preparations. J. Incl. Phenom. 2, 487-501. DOI: 10.1007/BF00662215.

Szejtli, J. 1998. Introduction and general overview of cyclodextrin chemistry. Chem. Rev. 98, 1743-1753.

Szente, L., Szejtli, J., Kis, G.L. 1998. Spontaneous opalescence of aqueous $\gamma$-cyclodextrin solutions: complex formation or self-aggregation. J. Pharm. Sci. 87, 778-781. DOI: $10.1021 /$ js 9704341 . 
Taccari, M., Milanovic, V., Comitini, F., Casucci, C., Ciani, M., 2012. Effects of biostimulation and bioaugmentation on diesel removal and bacterial community. Int. Biodeterior. Biodegrad. 66, 39-46. DOI: 10.1016/j.ibiod.2011.09.012.

Ti, Q., Gu, C., Liu, C., Cai, J., Bian, Y., Yang, X., Song, Y., Wang, F., Sun, C., Jiang, X., 2018. Comparative evaluation of influence of aging, soil properties and structural characteristics on bioaccessibility of polychlorinated biphenyls in soil. Chemosphere 210, 941-948. DOI: 10.1016/j.chemosphere.2018.07.111.

Tian, F., Guo, G., Ding, K., Wang, L., Liu, T., Yang, F., 2019. Effect of bioaugmentation by bacterial consortium and methyl- $\beta$-cyclodextrin on soil functional diversity and removal of polycyclic aromatic hydrocarbons. Polycyclic Arom. Compd. 39, 353-362. DOI: $10.1080 / 10406638.2017 .1326952$.

Tian, B., Liu, J. 2020. The classification and application of cyclodextrin polymers: a review. New J. Chem. 44, 9137-9148. DOI: 10.1039/c9nj05844c.

Trellu, C., Mousset, E., Pechaud, Y., Huguenot, D., van Hullebusch, E.D., Esposito, G., Oturan, M.A. 2016. Removal of hydrophobic organic pollutants from soil washing/flushing solutions: A critical review. J. Hazard. Mat. 306, 149-174. DOI: 10.1016/j.jhazmat.2015.12.008.

Verstichel S., De Wilde B., Fenyvesi E., Szejtli J., 2004. Investigation of the aerobic biodegradability of several types of cyclodextrins in a laboratory-controlled composting test. J. Polym. Environ. 12, 47-55. DOI: 10.1023/B: JOOE.0000010050.52967.94.

Villaverde, J., Morillo, E., Pérez-Martínez, J.I., Ginés, J.M., Maqueda, C. 2004. Preparation and characterization of inclusion complex of norflurazon and $\beta$-cyclodextrin to improve herbicide formulations. J. Agric. Food Chem. 52, 864-869. DOI: $10.1021 /$ jf0350358.

Villaverde, J., Pérez-Martínez, J.I., Maqueda, C., Ginés, J.M., Morillo, E. 2005a. Inclusion complexes of $\alpha$ - and $\gamma$-cyclodextrins and the herbicide norflurazon: $\mathrm{I}$. Preparation and characterisation. II. Enhanced solubilisation and removal from soils. Chemosphere 60, 656-664. DOI: 10.1016/j.chemosphere.2005.01.030.

Villaverde, J., Maqueda, C., Morillo, E. 2005b. Improvement of the desorption of the herbicide norflurazon from soils via complexation with $\beta$-cyclodextrin. J. Agric. Food Chem. 53, 5366-5372. DOI: 10.1021/jf0502449.

Villaverde, J., Maqueda, C., Morillo, E. 2006. Effect of the simultaneous addition of $\beta$ cyclodextrin and the herbicide norflurazon on its adsorption and movement in soils. J. Agric. Food Chem. 54, 4766-4772. DOI: 10.1021/jf060548a.

Villaverde, J., Maqueda, C., Undabeytia, T., Morillo, E., 2007. Effect of various cyclodextrins on photodegradation of a hydrophobic herbicide in aqueous suspensions of different soil colloidal components. Chemosphere 69, 575-584. DOI: 10.1016/j.chemosphere.2007.03.022.

Villaverde, J., Posada-Baquero, R., Rubio-Bellido, M., Laiz, L., Saiz-Jimenez, C., Sanchez-Trujillo, M.A., Morillo, E., 2012. Enhanced mineralization of diuron using a cyclodextrin-based bioremediation technology. J. Agric. Food Chem. 60, 9941-9947. DOI: $10.1021 /$ jf3021909. 
Villaverde J., Rubio-Bellido M., Posada-Baquero R., Madrid F., Morillo E., 2013a. Hydroxypropyl- $\beta$-cyclodextrin-based extraction for diuron bioaccessibility in an artificially contaminated soil. Int. J. Environ. Anal. Chem. 93, 1620-1627. DOI: 10.1080/03067319.2013.814120.

Villaverde, J., Posada-Baquero, R., Rubio-Bellido, M., Morillo, E., 2013b. Effect of hydroxypropyl- $\beta$-cyclodextrin on diuron desorption and mineralisation in soils. J. Soils Sediments 13, 1075-1083. DOI: 10.1007/s11368-013-0677-3.

Villaverde, J., Rubio-Bellido, M., Merchan, F., Morillo, E., 2017. Bioremediation of diuron contaminated soils by a novel degrading microbial consortium. J. Environ. Manag. 188, 379-386. DOI: 10.1016/j.jenvman.2016.12.020.

Villaverde J., Rubio-Bellido M., Lara-Moreno A., Merchan F., Morillo E., 2018. Combined use of microbial consortia isolated from different agricultural soils and cyclodextrin as a bioremediation technique for herbicide contaminated soils. Chemosphere 193, 118-125. DOI: 10.1016/j.chemosphere.2017.10.172.

Villaverde, J., Láiz, L., Lara-Moreno, A., González-Pimentel, JL., Morillo E., 2019. Bioaugmentation of PAH-contaminated soils with novel specific degrader strains isolated from a contaminated industrial site. Effect of hydroxypropyl- $\beta$-cyclodextrin as PAH bioavailability enhancer. Front. Microbiol. 10, 2588. DOI: 10.3389/fmicb.2019.02588.

Wan, C., Du, M., Lee, D.J., Yang, X., Ma, W., Zheng, L., 2011. Electrokinetic remediation and microbial community shift of $\beta$-cyclodextrin-dissolved petroleum hydrocarbon-contaminated soil. Appl. Microbiol. Biotechnol. 89, 2019-2025. DOI: $10.1007 / \mathrm{s} 00253-010-2952-1$.

Wang, G., Wang, Y., Hu, S., Deng, N., Wu, F. 2015. Cysteine- $\beta$-cyclodextrin enhanced phytoremediation of soil co-contaminated with phenanthrene and lead. Environ. Sci. Pollut. Res. 22, 10107-10115. DOI: 10.1007/s11356-015-4210-7.

Wang, G., Zhou, Y., Wang, X., Chai, X., Huang, L., Deng, N., 2010. Simultaneous removal of phenanthrene and lead from artificially contaminated soils with glycine- $\beta$ cyclodextrin. J. Hazard. Mater. 184, 690-695. DOI: 10.1016/j.jhazmat.2010.08.094.

Wang, G., Jiang, Y., Hu, S., Guo, Y., 2018. Aspartic acid- $\beta$-cyclodextrin-assisted phytoremediation of soil cocontaminated with cadmium and fluorene using alfalfa (Medicago sativa L.). Environ. Eng. Sci. 35, 279-288. DOI:10.1089/ees.2016.0460.

Weber, R., Schlumpf, M., Nakano, T., Vijgen, J., 2015. The need for better management and control of POPs stockpiles. Environ. Sci. Pollut. Res. 22, 14385-14390.

White, J.C., Peters, R., Kelsey, J.W. Surfactants differentially impact p,p'-DDE accumulation by plant and earthworm species. Environ. Sci. Tech. 41, 2007, 2922-2929. DOI: $10.1021 / \mathrm{es} 061893 \mathrm{j}$.

Wong F., Bidleman T.F., 2011. Aging of organochlorine pesticides and polychlorinated biphenyls in muck soil: volatilization, bioaccessibility, and degradation. Environ. Sci. Technol. 45, 958-963. DOI: 10.1021/es102825w.

Yang, C., Zeng, Q., Wang, Y., Liao, B., Sun, J., Shi, H., Chen, X., 2010. Simultaneous elution of polycyclic aromatic hydrocarbons and heavy metals from contaminated soil by two amino acids derived from $\beta$-cyclodextrins. J. Environ. Sci. 22, 1910-1915. DOI: 10.1016/S1001-0742(09)60338-7. 
Yáñez, C., Cañete-Rosales, P., Castillo, J.P., Catalán, N., Undabeytia, T., Morillo, E., 2012. Cyclodextrin inclusion complex to improve physicochemical properties of herbicide bentazon: exploring better formulations. PLoS ONE 2012. DOI: 10.1371/journal.pone.0041072.

Ye, M., Sun, M., Ni, N., Chen, Y., Liu, Z., Gu, C., Bian, Y., Hu, F., Li, H., Kengara, F.O., Jiang, X. 2014a. Role of cosubstrate and bioaccessibility played in the enhanced anaerobic biodegradation of organochlorine pesticides (OCPs) in a paddy soil by nitrate and methyl- $\beta$-cyclodextrin amendments. Environ. Sci. Pollut. Res. 21:7785-7796. DOI $10.1007 / \mathrm{s} 11356-014-2703-4$.

Ye, M., Sun, M., Liu, Z., Ni, N., Chen, Y., Gu, C., Kengara, F.O., Li, H., Jiang, X. 2014b. Evaluation of enhanced soil washing process and phytoremediation with maize oil, carboxymethyl-b-cyclodextrin, and vetiver grass for the recovery of organochlorine pesticides and heavy metals from a pesticide factory site. J. Environ. Manag. 141, 161168. DOI: 10.1016/j.jenvman.2014.03.025.

Ye, S., Zeng, G., Wu, H., Zhang, C., Dai, J., Liang, J., Yu, J., Ren, X., Yi, H., Cheng, M., Zhang, C., 2017. Biological technologies for the remediation of co-contaminated soil. Crit. Rev. Biotechnol. 37, 1062-1076. DOI: 10.1080/07388551.2017.1304357.

Yuan, C., Jin, Z. 2007. Aerobic biodegradability of hydroxypropyl- $\beta$-cyclodextrins in soil, J. Incl. Phenom. Macrocycl. Chem. 58, 345-351. DOI: 10.1007/s10847-006-92810 .

Yuan, C.L., Xu, Z.Z., Fan, M.X., Liu, H.Y., Xie, Y.H., Zhu, T. 2014. Study on characteristics and harm of surfactants. J. Chem. Pharm. Res. 6, 2233-2237.

Zhang, W., Liu, Y.G., Tan, X.F., Zeng, G.M., Gong, J.L., Lai, C., Niu, Q.Y., Tang, Y.Q., 2019. Enhancement of detoxification of petroleum hydrocarbons and heavy metals in oilcontaminated soil by using glycine- $\beta$-cyclodextrin. Int. J. Environ. Res. Public Health, 16, 1155. DOI:10.3390/ijerph16071155.

Zhang, T., Liu, Y., Zhong, S., Zhang, L., 2020a. AOPs-based remediation of petroleum hydrocarbons-contaminated soils: Efficiency, influencing factors and environmental impacts. Chemosphere, 246, 125726. DOI: 10.1016/j.chemosphere.2019.125726.

Zhang, H., Yuan, X., Xiong, T., Wang, H., Jiang, L. 2020b. Bioremediation of cocontaminated soil with heavy metals and pesticides: Influence factors, mechanisms and evaluation methods. Chemical Engineering Journal 398, 125657. DOI: 10.1016/j.cej.2020.125657.

Zhao J., Chi Y., Liu F., Jia D., Yao K., 2015. Effects of Two Surfactants and BetaCyclodextrin on Beta-Cypermethrin Degradation by Bacillus licheniformis B-1. J. Agric. Food Chem. 63, 10729-10735. DOI: 10.1021/acs.jafc.5b04485.

Zhao L., Guo W., Zhao W., Long M., Li H., 2017. Effect of three kinds of surfactants and $\beta$-cyclodextrin on the phytoremediation of BDE-209 contaminated sediment. International Symposium on Resource Exploration and Environmental Science. IOP Conf. Series: Earth and Environ. Sci. 64, 012115. DOI:10.1088/1755-1315/64/1/012115. 


\section{Figure legend}

Figure 1. Bioavailable and bioaccessible fractions of an organic pollutant in soil (adapted from Semple et al., 2004). 


\section{Credit Author Statement}

Esmeralda Morillo: Conceptualization, Writing - Original Draft, Project administration, Funding acquisition

Fernando: Investigation, Supervision, Writing- Reviewing and Editing

Alba: Investigation, Visualization

Jaime: Visualization, Resources, Writing - Review \& Editing 


\section{Declaration of interests}

The authors declare that they have no known competing financial interests or personal relationships that could have appeared to influence the work reported in this paper. 

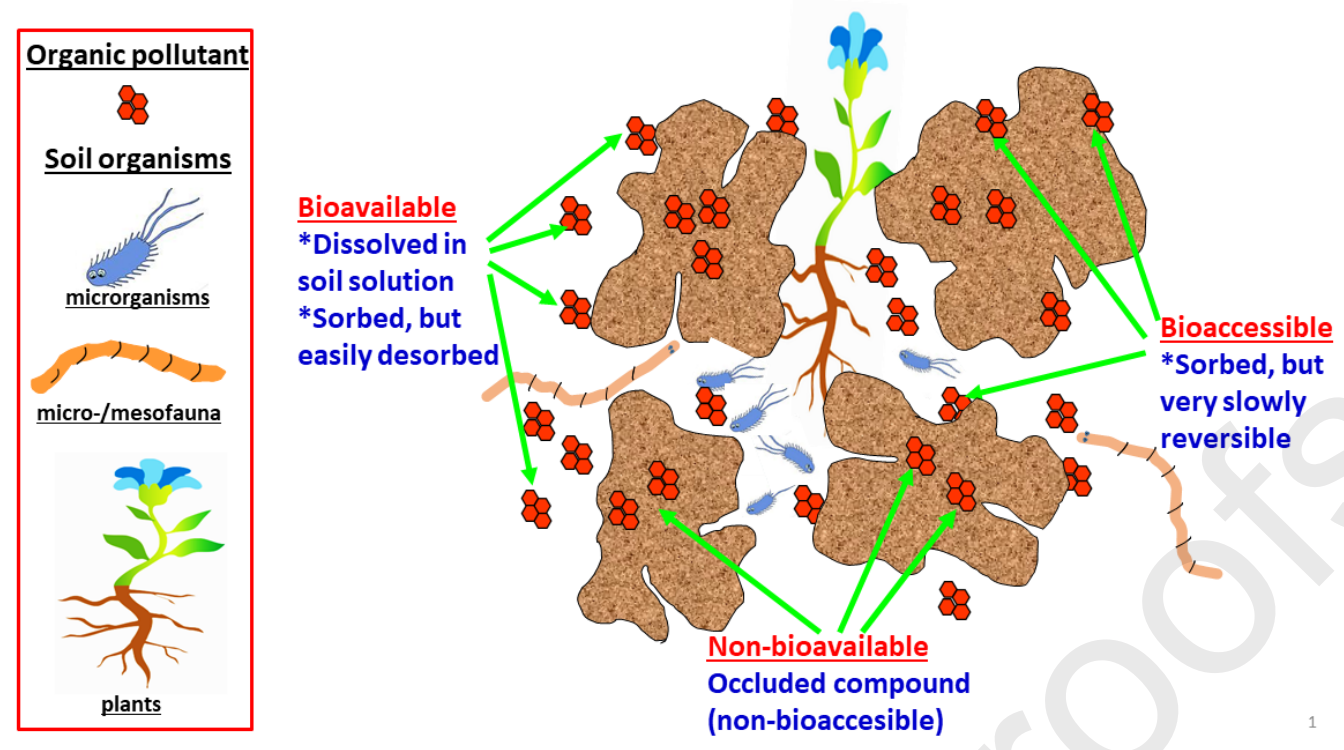


\begin{tabular}{|c|c|c|c|c|c|}
\hline PAHs & $\begin{array}{l}\text { Scale/ } \\
\text { Contaminatio } \\
\mathbf{n}\end{array}$ & $\begin{array}{l}\text { Bioremediatio } \\
\text { n Technique }\end{array}$ & $\begin{array}{l}\text { Microorganisms / } \\
\text { CDs }\end{array}$ & Achievements & $\begin{array}{l}\text { Refere } \\
\text { nces }\end{array}$ \\
\hline Fluorene & $\begin{array}{l}\text { Laboratory/ } \\
\text { Artificially spiked } \\
\text { soil }\end{array}$ & Bioaugmentation & $\begin{array}{l}\text { Exogenous fungal strain / } \\
\text { maltosyl-cyclodextrin }\end{array}$ & $\begin{array}{l}5 \% \text { FLU degraded in } \\
\text { the control after } 72 \mathrm{~h} \text {. } \\
\text { Up to } 65 \% \text { after } \\
\text { addition of fungal } \\
\text { strain. Up to } 80 \% \text { with } \\
\text { MCD + fungal strain. }\end{array}$ & $\begin{array}{l}\text { Garon et } \\
\text { al. } \\
(2004 b)\end{array}$ \\
\hline $\begin{array}{l}\text { Phenanthr } \\
\text { ene }\end{array}$ & $\begin{array}{l}\text { Laboratory/ } \\
\text { Artificially spiked } \\
\text { and aged soil }\end{array}$ & Bioaugmentation & $\begin{array}{l}\text { Exogenous bacterial } \\
\text { strain / } \\
\text { Hydroxypropyl- } \beta- \\
\text { cyclodextrin }\end{array}$ & $\begin{array}{l}\text { Lower mineralization } \\
\text { with } \mathrm{HPBCD} \text { than in } \\
\text { the control, and } \\
\text { decreased as } \mathrm{CD} \\
\text { concentration } \\
\text { increased. }\end{array}$ & $\begin{array}{l}\text { Reid et al. } \\
\text { (2004) }\end{array}$ \\
\hline $\begin{array}{l}\text { Several } \\
\text { PAHs }\end{array}$ & $\begin{array}{l}\text { Laboratory/ } \\
\text { Real contaminated } \\
\text { soils (3) artificially } \\
\text { spiked with PHE } \\
\text { and PYR }\end{array}$ & $\begin{array}{l}\text { Bioaugmentation and } \\
\text { biostimulation } \\
\text { (macro- and } \\
\text { micronutrients) }\end{array}$ & $\begin{array}{l}\text { Cultures of exogenous } \\
\text { bacterial strains and } \\
\text { microbial consortia / } \\
\text { Hydroxypropyl- } \beta \text { - } \\
\text { cyclodextrin }\end{array}$ & $\begin{array}{l}\text { HPBCD lowered } \\
\text { biodegradation } \\
\text { endpoints for most } \\
\text { PAHs. Spiked PYR was } \\
\text { more accessible to } \\
\text { microorganisms than } \\
\text { aged PYR, but for PHE } \\
\text { it was similar. }\end{array}$ & $\begin{array}{l}\text { Allan et } \\
\text { al. (2007) }\end{array}$ \\
\hline $\begin{array}{l}\text { Several } \\
\text { PAHs }\end{array}$ & $\begin{array}{l}\text { Field scale (6 } \\
\text { months) / } \\
\text { Artificially spiked } \\
\text { soil }\end{array}$ & $\begin{array}{l}\text { Bioaugmentation and } \\
\text { biostimulation (urea) }\end{array}$ & $\begin{array}{l}\text { Exogenous microbial } \\
\text { consortium / } \\
\beta \text {-cyclodextrin }\end{array}$ & $\begin{array}{l}\text { BCD enhanced } \\
\text { bioremediation, but } \\
\text { the microbial } \\
\text { consortium did not } \\
\text { improve it. }\end{array}$ & $\begin{array}{l}\text { Bardi et } \\
\text { al. (2007) }\end{array}$ \\
\hline $\begin{array}{l}\text { Several } \\
\text { PAHs }\end{array}$ & $\begin{array}{l}\text { Laboratory/ } \\
\text { Artificially spiked } \\
\text { soil }\end{array}$ & Bioaugmentation & $\begin{array}{l}\text { Exogenous fungal strains } \\
\text { RAMEB }\end{array}$ & $\begin{array}{l}\text { Residual } \\
\text { concentration of } 7 \\
\text { PAHs decreased after } \\
6 \text { weeks incubation. } \\
\end{array}$ & $\begin{array}{l}\text { Leonardi } \\
\text { et al. } \\
(2008)\end{array}$ \\
\hline $\begin{array}{l}\text { Phenanthr } \\
\text { ene }\end{array}$ & $\begin{array}{l}\text { Laboratory/ } \\
\text { Artificially spiked } \\
\text { soil }\end{array}$ & Bioaugmentation & $\begin{array}{l}\text { Exogenous bacterial } \\
\text { strain / } \\
\text { Hydroxypropyl- } \beta- \\
\text { cyclodextrin }\end{array}$ & $\begin{array}{l}\text { HPBCD had no impact } \\
\text { on PHE degradation. }\end{array}$ & $\begin{array}{l}\text { Stroud et } \\
\text { al. (2009) }\end{array}$ \\
\hline $\begin{array}{l}\text { Naphthale } \\
\text { ne }\end{array}$ & $\begin{array}{l}\text { Laboratory/ } \\
\text { Artificially spiked } \\
\text { soil }\end{array}$ & $\begin{array}{l}\text { Bioaugmentation and } \\
\text { biostimulation } \\
\text { (nitrate) }\end{array}$ & $\begin{array}{l}\text { Exogenous bacterial } \\
\text { consortia / } \\
\text { Hydroxypropyl- } \beta- \\
\text { cyclodextrin }\end{array}$ & $\begin{array}{l}\text { NAP degradation } \\
\text { enhanced two times } \\
\text { when using HPBCD. }\end{array}$ & $\begin{array}{l}\text { Dou et al. } \\
\text { (2011) }\end{array}$ \\
\hline $\begin{array}{l}\text { Several } \\
\text { PAHs }\end{array}$ & $\begin{array}{l}\text { Microcosms } \\
\text { experiments } \\
\text { / Real } \\
\text { contaminated soil }\end{array}$ & Bioaugmentation & $\begin{array}{l}\text { Exogenous bacterial } \\
\text { strain / } \\
\text { Methyl- } \beta \text {-cyclodextrin }\end{array}$ & $\begin{array}{l}5 \% \text { degraded in the } \\
\text { control after } 16 \\
\text { weeks. Up to } 25 \% \\
\text { after addition of } \\
\text { MBCD. } 35 \% \text { with } \\
\text { MBCD + bacterial } \\
\text { strain. }\end{array}$ & $\begin{array}{l}\text { Sun et al. } \\
(2012)\end{array}$ \\
\hline $\begin{array}{l}\text { Several } \\
\text { PAHs }\end{array}$ & $\begin{array}{l}\text { Microcosms } \\
\text { experiments } \\
\text { / Real } \\
\text { contaminated soil }\end{array}$ & Bioaugmentation & $\begin{array}{l}\text { Exogenous bacterial } \\
\text { strain / } \\
\text { Methyl- } \beta \text {-cyclodextrin }\end{array}$ & $\begin{array}{l}\text { Ex situ cleanup of the } \\
\text { soil with MBCD to } \\
\text { extract PAHs ( } 93 \% \\
\text { removed) and metals, } \\
\text { and bioaugmentation } \\
\text { to treat residual PAHs } \\
\text { in soil. }\end{array}$ & $\begin{array}{l}\text { Sun et al. } \\
\text { (2013a) }\end{array}$ \\
\hline $\begin{array}{l}\text { Several } \\
\text { PAHs }\end{array}$ & $\begin{array}{l}\text { Microcosms } \\
\text { experiments } \\
\text { / Real } \\
\text { contaminated soil }\end{array}$ & Bioaugmentation & $\begin{array}{l}\text { Exogenous bacterial } \\
\text { strain / } \\
\text { Methyl- } \beta \text {-cyclodextrin }\end{array}$ & $\begin{array}{l}\text { MBCD amendment at } \\
10 \%(w / w)+ \\
\text { inoculation produced } \\
\text { maximum PAHs } \\
\text { removal }(35 \%) \text { after } \\
32 \text { weeks. }\end{array}$ & $\begin{array}{l}\text { Sun et al. } \\
(2013 b)\end{array}$ \\
\hline $\begin{array}{l}\text { Several } \\
\text { PAHs }\end{array}$ & $\begin{array}{l}\text { Microcosms } \\
\text { experiments } \\
\text { / Real } \\
\text { contaminated soil }\end{array}$ & $\begin{array}{l}\text { Biostimulation } \\
\text { (nitrate) }\end{array}$ & $\begin{array}{l}\text { Endogenous microbiota / } \\
\text { Methyl- } \beta \text {-cyclodextrin }\end{array}$ & $\begin{array}{l}\text { Anaerobic } \\
\text { biodegradation limited } \\
\text { by lack of electron } \\
\text { acceptors (nitrate). } \\
\text { MCD } 1 \%(\mathrm{w} / \mathrm{w}) \text { and } 20 \\
\mathrm{mM} \text { nitrate produced }\end{array}$ & $\begin{array}{l}\text { Sun et al. } \\
\text { (2014) }\end{array}$ \\
\hline
\end{tabular}




\begin{tabular}{|c|c|c|c|c|c|}
\hline & & & & $\begin{array}{l}\text { the maximum PAHs } \\
\text { biodegradation }(62 \%) \text {. }\end{array}$ & \\
\hline $\begin{array}{l}\text { Pyrene } \\
\text { Fluorene }\end{array}$ & $\begin{array}{l}\text { Laboratory/ } \\
\text { Artificially spiked } \\
\text { soil }\end{array}$ & - & $\begin{array}{l}\text { Endogenous microbiota / } \\
\text { Hydroxypropyl- } \beta- \\
\text { cyclodextrin }\end{array}$ & $\begin{array}{l}\text { Fluorene dissipation } \\
\text { primarily due to } \\
\text { volatilization. }<5 \% \text { PYR } \\
\text { after } 30 \text { days in the } \\
\text { presence of HPBCD, } \\
\text { and } 33 \% \text { in its } \\
\text { absence. Fluorene } \\
\text { inhibited PYR } \\
\text { biodegradation. }\end{array}$ & $\begin{array}{l}\text { Madrid et } \\
\text { al. (2016) }\end{array}$ \\
\hline $\begin{array}{l}\text { Several } \\
\text { PAHs }\end{array}$ & $\begin{array}{l}\text { Laboratory and } \\
\text { field scale (13 } \\
\text { months) / Real } \\
\text { contaminated soil }\end{array}$ & $\begin{array}{l}\text { Biostimulation } \\
\text { (nutrients) }\end{array}$ & $\begin{array}{l}\text { Endogenous microbiota / } \\
\text { Methyl- } \beta \text {-cyclodextrin }\end{array}$ & $\begin{array}{l}\text { 2,3-ring PAHs } \\
\text { degraded with only } \\
\text { nutrients, 4,5-ring } \\
\text { PAHs with nutrients + } \\
\text { MBCD, >5-ring very } \\
\text { low degradation. }\end{array}$ & $\begin{array}{l}\text { Simpanen } \\
\text { et al. } \\
(2016)\end{array}$ \\
\hline $\begin{array}{l}\text { Pyrene } \\
\text { Benzo[a]p } \\
\text { yrene }\end{array}$ & $\begin{array}{l}\text { Laboratory/ } \\
\text { Artificially spiked } \\
\text { soil }\end{array}$ & $\begin{array}{l}\text { Biostimulation } \\
\text { (Humic substances, } \\
\text { HS) }\end{array}$ & $\begin{array}{l}\text { Endogenous microbiota / } \\
\text { Hydroxypropyl- } \beta- \\
\text { cyclodextrin }\end{array}$ & $\begin{array}{l}\text { PYR degradation } \\
\text { increased from } 28 \% \text { to } \\
40 \% \text { in the presence of } \\
\text { HPBCD after } 98 \text { days. } \\
\text { B[a]PYR only from } \\
2.8 \% \text { to } 4 \% \text {. } \\
\text { HS+HPBCD increased } \\
\text { B[a]PYR degradation } \\
\text { up to } 10 \% \text {, but } \\
\text { decreased PYR at } 32 \% \text {. }\end{array}$ & $\begin{array}{l}\text { Liu et al. } \\
\text { (2018) }\end{array}$ \\
\hline $\begin{array}{l}\text { Several } \\
\text { PAHs }\end{array}$ & $\begin{array}{l}\text { Microcosms } \\
\text { experiments/ } \\
\text { Real contaminated } \\
\text { soil }\end{array}$ & Bioaugmentation & $\begin{array}{l}\text { Endogenous microbial } \\
\text { consortium (MC) / } \\
\text { Hydroxypropyl- } \beta- \\
\text { cyclodextrin }\end{array}$ & $\begin{array}{l}\text { The best results for 4- } \\
\text { ring PAHs with } \\
\text { HPBCD+MC (up to } \\
48 \% \text { degradation for } \\
\text { pyrene and } 43 \% \text { for } \\
\text { fluoranthene) in } 120 \\
\text { days. Very low } \\
\text { dissipation of 5-ring } \\
\text { PAHs, and negligible } \\
\text { for 6-ring. }\end{array}$ & $\begin{array}{l}\text { Madrid et } \\
\text { al. } \\
\text { (2019a) }\end{array}$ \\
\hline $\begin{array}{l}\text { Pyrene } \\
\text { Benzo[a]p } \\
\text { yrene }\end{array}$ & $\begin{array}{l}\text { Laboratory/ } \\
\text { Artificially spiked } \\
\text { soil }\end{array}$ & Bioaugmentation & $\begin{array}{l}\text { Exogenous bacterial } \\
\text { consortium / Methyl- } \beta- \\
\text { cyclodextrin }\end{array}$ & $\begin{array}{l}30 \% \text { PYR and } 11 \% \\
\text { B[a]PYR degraded } \\
\text { after } 4 \text { weeks, } 18 \% \\
\text { and } 4 \% \text { without the } \\
\text { CD. }\end{array}$ & $\begin{array}{l}\text { Tian et al. } \\
\text { (2019) }\end{array}$ \\
\hline Pyrene & $\begin{array}{l}\text { Laboratory/ } \\
\text { Artificially spiked } \\
\text { and aged soil }\end{array}$ & Bioaugmentation & $\begin{array}{l}\text { Exogenous bacterial } \\
\text { strains / Hydroxypropyl- } \\
\text { B-cyclodextrin }\end{array}$ & $\begin{array}{l}34 \% \text { PYR } \\
\text { mineralization after } \\
\text { treatment with HPBCD } \\
\text { for } 180 \text { days, } \\
\text { decreased to } 25 \% \\
\text { when } \\
\text { bioaugmentation was } \\
\text { added }\end{array}$ & $\begin{array}{l}\text { Villaverde } \\
\text { et al. } \\
\text { (2019) }\end{array}$ \\
\hline
\end{tabular}

Table 1. Selected reports on the use of cyclodextrins in bioremediation by microorganisms of PAHs contaminated soils. 


\begin{tabular}{|c|c|c|c|c|c|}
\hline $\begin{array}{l}\text { Pesticid } \\
\text { es }\end{array}$ & $\begin{array}{l}\text { Scale/ } \\
\text { Contaminatio } \\
\mathbf{n}\end{array}$ & $\begin{array}{l}\text { Bioremediatio } \\
\text { n Technique }\end{array}$ & $\begin{array}{l}\text { Microorganisms / } \\
\text { CDs }\end{array}$ & Achievements & $\begin{array}{l}\text { Refere } \\
\text { nces }\end{array}$ \\
\hline Diuron & $\begin{array}{l}\text { Laboratory/ } \\
\text { Artificially spiked } \\
\text { soil }\end{array}$ & $\begin{array}{l}\text { Biostimulation } \\
\text { (micronutrients) } \\
\text { Bioaugmentation }\end{array}$ & $\begin{array}{l}\text { Two-strain Exogenous } \\
\text { bacterial consortium/ } \\
\text { Hydroxypropyl- } \beta- \\
\text { cyclodextrin }\end{array}$ & $\begin{array}{l}98 \% \text { mineralised after } \\
120 \text { days } \\
45 \% \text { only with the } \\
\text { consortium }\end{array}$ & $\begin{array}{l}\text { Villaverde } \\
\text { et al. } \\
(2012)\end{array}$ \\
\hline Diuron & $\begin{array}{l}\text { Laboratory/ } \\
\text { Artificially spiked } \\
\text { soil }\end{array}$ & $\begin{array}{l}\text { Biostimulation } \\
\text { (micronutrients) }\end{array}$ & $\begin{array}{l}\text { Endogenous microbiota/ } \\
\text { Hydroxypropyl- } \beta- \\
\text { cyclodextrin }\end{array}$ & $\begin{array}{l}66 \% \text { mineralised after } \\
100 \text { days } \\
44 \% \text { only with } \\
\text { micronutrients }\end{array}$ & $\begin{array}{l}\text { Villaverde } \\
\text { et al. } \\
\text { (2013) }\end{array}$ \\
\hline $\begin{array}{l}\text { Organochl } \\
\text { orine } \\
\text { pesticides } \\
\text { (OCPs) }\end{array}$ & $\begin{array}{l}\text { Laboratory/ } \\
\text { Aged } \\
\text { contaminated soil }\end{array}$ & $\begin{array}{l}\text { Biostimulation } \\
\left(\mathrm{KNO}_{3}\right)\end{array}$ & $\begin{array}{l}\text { Endogenous microbiota / } \\
\text { Methyl- } \beta \text {-cyclodextrin }\end{array}$ & $\begin{array}{l}65 \% \text { OCPs } \\
\text { biodegraded after } 180 \\
\text { days with } \\
\text { nitrate+MBCD. } 40 \% \\
\text { with only nitrate. } 15 \% \\
\text { with only MBCD. }\end{array}$ & $\begin{array}{l}\text { Ye et al. } \\
\text { (2014) }\end{array}$ \\
\hline $\begin{array}{l}\text { DDTs } \\
\text { (DDT and } \\
\text { derivatives } \\
\text { ) }\end{array}$ & $\begin{array}{l}\text { Laboratory/ } \\
\text { Artificially spiked } \\
\text { and aged soils (4) }\end{array}$ & Bioaugmentation & $\begin{array}{l}\text { Exogenous bacterial } \\
\text { strain/ } \\
\text { Hydroxypropyl- } \beta- \\
\text { cyclodextrin }\end{array}$ & $\begin{array}{l}\text { DDTs degradation } \\
\text { inhibited in the } \\
\text { presence of HPBCD }\end{array}$ & $\begin{array}{l}\text { Gao et al. } \\
(2015)\end{array}$ \\
\hline Diuron & $\begin{array}{l}\text { Laboratory/ } \\
\text { Artificially spiked } \\
\text { soil }\end{array}$ & $\begin{array}{l}\text { Biostimulation } \\
\text { (micronutrients, and } \\
\text { sewage sludge and } \\
\text { urban solid residues } \\
\text { composts) }\end{array}$ & $\begin{array}{l}\text { Endogenous microbiota/ } \\
\text { Hydroxypropyl- } \beta- \\
\text { cyclodextrin }\end{array}$ & $\begin{array}{l}15 \% \text { mineralised with } \\
\text { only micronutrients } \\
\text { after } 140 \text { days. } 30 \% \\
\text { with only HPBCD. } \\
46.5 \% \text { with HPBCD } \\
\text { and one of the } \\
\text { composts. }\end{array}$ & $\begin{array}{l}\text { Rubio- } \\
\text { Bellido et } \\
\text { al. (2015) }\end{array}$ \\
\hline Diuron & $\begin{array}{l}\text { Laboratory/ } \\
\text { Artificially spiked } \\
\text { soils (4) }\end{array}$ & $\begin{array}{l}\text { Biostimulation } \\
\text { (micronutrients) }\end{array}$ & $\begin{array}{l}\text { Endogenous microbiota/ } \\
\text { Hydroxypropyl- } \beta \text { - } \\
\text { cyclodextrin }\end{array}$ & $\begin{array}{l}\text { Different percentages } \\
\text { mineralized depending } \\
\text { on soil properties (up } \\
\text { to } 47 \% \text { after } 150 \text { days) }\end{array}$ & $\begin{array}{l}\text { Rubio- } \\
\text { Bellido et } \\
\text { al. (2016) }\end{array}$ \\
\hline $\begin{array}{l}\text { Chlorpyrif } \\
\text { os (CPF) } \\
\text { Diazinon } \\
\text { (DZN) }\end{array}$ & $\begin{array}{l}\text { Laboratory/ } \\
\text { Artificially spiked } \\
\text { soils (4) }\end{array}$ & & $\begin{array}{l}\text { Endogenous microbiota/ } \\
\beta \text {-cyclodextrin for CPF, } \\
\text { Methyl- } \beta \text {-cyclodextrin } \\
\text { for DZN }\end{array}$ & $\begin{array}{l}\text { Slower rates of } \\
\text { degradation of CPF } \\
\text { and DZN in the } \\
\text { presence of the CDs, } \\
\text { due to the stability of } \\
\text { the inclusion } \\
\text { complexes. }\end{array}$ & $\begin{array}{l}\text { Báez et al. } \\
\text { (2018) }\end{array}$ \\
\hline Diuron & $\begin{array}{l}\text { Laboratory/ } \\
\text { Artificially spiked } \\
\text { soil }\end{array}$ & $\begin{array}{l}\text { Biostimulation } \\
\text { (micronutrients) } \\
\text { Bioaugmentation }\end{array}$ & $\begin{array}{l}\text { Exogenous bacterial } \\
\text { consortia from } 5 \\
\text { agricultural soils/ } \\
\text { Hydroxypropyl- } \beta \text { - } \\
\text { cyclodextrin }\end{array}$ & $\begin{array}{l}13 \% \text { mineralized with } \\
\text { only micronutrients, } \\
27 \% \text { with HPBCD, } 23 \% \\
\text { with the most } \\
\text { effective consortium, } \\
42 \% \text { with HPBCD + the } \\
\text { selected consortium. }\end{array}$ & $\begin{array}{l}\text { Villaverde } \\
\text { et al. } \\
\text { (2018) }\end{array}$ \\
\hline
\end{tabular}

Table 2. Selected reports on the use of cyclodextrins in bioremediation by microorganisms of pesticide contaminated soils. 


\begin{tabular}{|c|c|c|c|c|c|}
\hline PCBs & $\begin{array}{l}\text { Scale/ } \\
\text { Contaminatio } \\
\mathbf{n}\end{array}$ & $\begin{array}{l}\text { Bioremediatio } \\
\text { n Technique }\end{array}$ & $\begin{array}{l}\text { Microorganisms / } \\
\text { CDs }\end{array}$ & Achievements & $\begin{array}{l}\text { Refere } \\
\text { nces }\end{array}$ \\
\hline $\begin{array}{l}\text { Several } \\
\text { PCBs (27) }\end{array}$ & $\begin{array}{l}\text { Laboratory and } \\
\text { microcosms } \\
\text { experiments / } \\
\text { Real aged } \\
\text { contaminated soil }\end{array}$ & $\begin{array}{l}\text { Bioaugmentation } \\
\text { Biostimulation } \\
\left(\mathrm{NH}_{4} \mathrm{NO}_{3}, \mathrm{KH}_{2} \mathrm{PO}_{4}\right. \\
\text { biphenyl) }\end{array}$ & $\begin{array}{l}\text { Endogenous microbiota / } \\
\text { Hydroxypropyl- } \beta \text { - } \\
\text { cyclodextrin, } \\
\gamma \text {-cyclodextrin }\end{array}$ & $\begin{array}{l}\text { High depletion for } \\
\text { low- and high- } \\
\text { chlorinated PCBs after } \\
141 \text { days. } \gamma \text {-CD less } \\
\text { effective than HPBCD. }\end{array}$ & $\begin{array}{l}\text { Fava et al. } \\
\text { (1998) }\end{array}$ \\
\hline $\begin{array}{l}\text { Several } \\
\text { PCBs }\end{array}$ & $\begin{array}{l}\text { Laboratory/ } \\
\text { Artificially spiked } \\
\text { soils (3) }\end{array}$ & $\begin{array}{l}\text { Bioaugmentation } \\
\text { Biostimulation } \\
\left(\mathrm{NH}_{4} \mathrm{NO}_{3} \text {, biphenyl) }\right.\end{array}$ & $\begin{array}{l}\text { Exogenous bacterial } \\
\text { consortium / } \\
\text { RAMEB }\end{array}$ & $\begin{array}{l}\text { RAMEB enhanced PCB } \\
\text { degradation after } 90 \\
\text { days, but depending } \\
\text { on the CD } \\
\text { concentration and soil } \\
\text { properties. }\end{array}$ & $\begin{array}{l}\text { Fava and } \\
\text { Ciccotost } \\
\text { o (2002) }\end{array}$ \\
\hline $\begin{array}{l}\text { Several } \\
\text { PCBs (>54) }\end{array}$ & $\begin{array}{l}\text { Laboratory/ } \\
\text { Aged } \\
\text { contaminated soils } \\
\text { (2) }\end{array}$ & $\begin{array}{l}\text { Bioestimulation } \\
\text { (biphenyl) }\end{array}$ & $\begin{array}{l}\text { Endogenous microbiota / } \\
\text { RAMEB }\end{array}$ & $\begin{array}{l}\text { PCBs degradation } \\
\text { inhibited in one of the } \\
\text { contaminated soils as } \\
\text { RAMEB concentration } \\
\text { increased. The } \\
\text { contrary occurs in the } \\
\text { other soil. }\end{array}$ & $\begin{array}{l}\text { Fava et al. } \\
\text { (2002) }\end{array}$ \\
\hline $\begin{array}{l}\text { Several } \\
\text { PCBs }\end{array}$ & $\begin{array}{l}\text { Microcosms } \\
\text { experiments / } \\
\text { Aged } \\
\text { contaminated soils } \\
\text { (2) }\end{array}$ & $\begin{array}{l}\text { Bioestimulation ( } \\
\mathrm{NH}_{4} \mathrm{NO}_{3} \text {, biphenyl) }\end{array}$ & $\begin{array}{l}\text { Endogenous microbiota / } \\
\text { RAMEB }\end{array}$ & $\begin{array}{l}\text { Average depletion of } \\
\text { PCBs increased up to } \\
14 \% \text { in one soil and } \\
23 \% \text { in the other after } \\
\text { six months when using } \\
\text { the highest CD } \\
\text { concentration. }\end{array}$ & $\begin{array}{l}\text { Fava et al. } \\
\text { (2003) }\end{array}$ \\
\hline $\begin{array}{l}\text { Several } \\
\text { PCBs }\end{array}$ & $\begin{array}{l}\text { Microcosms } \\
\text { experiments / } \\
\text { Aged } \\
\text { contaminated soil }\end{array}$ & $\begin{array}{l}\text { Bioestimulation ( } \\
\mathrm{NH}_{4} \mathrm{NO}_{3} \text {, biphenyl) }\end{array}$ & $\begin{array}{l}\text { Endogenous microbiota / } \\
\text { RAMEB }\end{array}$ & $\begin{array}{l}\text { Changes in the soil } \\
\text { bacterial community } \\
\text { structure during PCB } \\
\text { degradation using } \\
\text { RAMEB. }\end{array}$ & $\begin{array}{l}\text { Fedi et al. } \\
(2005)\end{array}$ \\
\hline $\begin{array}{l}\text { Several } \\
\text { PCBs (17) }\end{array}$ & $\begin{array}{l}\text { Laboratory/ } \\
\text { Artificially spiked } \\
\text { soils (2) }\end{array}$ & $\begin{array}{l}\text { Biostimulation } \\
\text { (biphenyl, plant } \\
\text { secondary } \\
\text { metabolites) }\end{array}$ & $\begin{array}{l}\text { Endogenous microbiota / } \\
\text { Hydroxypropyl- } \beta- \\
\text { cyclodextrin }\end{array}$ & $\begin{array}{l}\text { No effect of only } \\
\text { HPBCD on } \\
\text { enhancement of PCB } \\
\text { removal. } \\
\text { HPBCD decreased PCB } \\
\text { removal reached by } \\
\text { biphenyl amendment. }\end{array}$ & $\begin{array}{l}\text { Luo et al. } \\
\text { (2007) }\end{array}$ \\
\hline $\begin{array}{l}\text { Several } \\
\text { PCBs }\end{array}$ & $\begin{array}{l}\text { Laboratory/ } \\
\text { Aged } \\
\text { contaminated soil }\end{array}$ & - & $\begin{array}{l}\text { Endogenous microbiota/ } \\
\text { RAMEB }\end{array}$ & $\begin{array}{l}\text { Enhanced removal of } \\
\text { tri-CBs by RAMEB } \\
\text { ( } 44 \% \text { in } 100 \text { days). } \\
\text { Tetra- and high } \\
\text { chlorinated PCBs was } \\
\text { no significant. }\end{array}$ & $\begin{array}{l}\text { Hu et al. } \\
\text { (2016) }\end{array}$ \\
\hline
\end{tabular}

Table 3. Selected reports on the use of cyclodextrins in bioremediation by microorganisms of PCBs contaminated soils. 


\begin{tabular}{|c|c|c|c|c|c|}
\hline $\begin{array}{l}\text { Contam } \\
\text { inant }\end{array}$ & $\begin{array}{l}\text { Scale/ } \\
\text { Contaminatio } \\
\mathbf{n}\end{array}$ & $\begin{array}{l}\text { Bioremediatio } \\
\text { n Technique }\end{array}$ & $\begin{array}{l}\text { Microorganisms / } \\
\text { CDs }\end{array}$ & Achievements & $\begin{array}{l}\text { Referen } \\
\text { ces }\end{array}$ \\
\hline $\begin{array}{l}\text { Diesel oil } \\
\text { Mineral oil }\end{array}$ & $\begin{array}{l}\text { Laboratory/ } \\
\text { Real and artificially } \\
\text { contaminated soils. }\end{array}$ & Bioaugmentation & $\begin{array}{l}\text { Unspecified / } \\
\text { RAMEB }\end{array}$ & $\begin{array}{l}\text { No differences in } \\
\text { degradation of } \\
\text { diesel oil after using } \\
C D \text { for } 3 \text { months, but } \\
\text { high degradation in } \\
\text { soils with mineral } \\
\text { oil. }\end{array}$ & $\begin{array}{l}\text { Gruiz et al. } \\
\text { (1996) }\end{array}$ \\
\hline $\begin{array}{l}\text { Diesel } \\
\text { Transform } \\
\text { er oil }\end{array}$ & $\begin{array}{l}\text { Laboratory/ } \\
\text { Spiked and real } \\
\text { contaminated soils }\end{array}$ & $\begin{array}{l}\text { Biostimulation }(\mathrm{N} \text {, } \\
\text { P) }\end{array}$ & $\begin{array}{l}\text { Endogenous microbiota / } \\
\text { RAMEB }\end{array}$ & $\begin{array}{l}\text { Increased } \\
\text { degradation after } 4 \\
\text { weeks treatment, } \\
\text { but depending on } \\
\text { the soil properties } \\
\text { (up to } 60 \% \text { in humic- } \\
\text { loamy soil). }\end{array}$ & $\begin{array}{l}\text { Molnar et } \\
\text { al. (2003) }\end{array}$ \\
\hline $\begin{array}{l}\text { Transform } \\
\text { er oil }\end{array}$ & $\begin{array}{l}\text { Field experiments in } \\
\text { situ/ } \\
\text { real contaminated } \\
\text { soils (2) }\end{array}$ & $\begin{array}{l}\text { Biostimulation (N, P, } \\
\mathrm{K} \text { ) } \\
\text { Bioaugmentation in } \\
\text { one of the soils }\end{array}$ & $\begin{array}{l}\text { Endogenous microbiota / } \\
\text { RAMEB }\end{array}$ & $\begin{array}{l}\text { Oil content } \\
\text { decreased from } \\
25.000 \text { to } 900 \mathrm{mg} \mathrm{kg} \\
1\end{array}$ & $\begin{array}{l}\text { Leitgib et al. } \\
(2003)\end{array}$ \\
\hline $\begin{array}{l}\text { Aliphatic } \\
\text { hydrocarb } \\
\text { ons (HCs) }\end{array}$ & $\begin{array}{l}\text { Field experiments in } \\
\text { situ/ } \\
\text { real contaminated } \\
\text { soil }\end{array}$ & $\begin{array}{l}\text { Bioaugmentation } \\
\text { Biostimulation (N, } \\
\text { P) }\end{array}$ & $\begin{array}{l}\text { Endogenous microbiota / } \\
\beta \text {-cyclodextrin }\end{array}$ & $\begin{array}{l}\text { HCs nearly } \\
\text { completely } \\
\text { degraded after } 3 \\
\text { months }\end{array}$ & $\begin{array}{l}\text { Bardi et al. } \\
\text { (2003) }\end{array}$ \\
\hline $\begin{array}{l}\text { Transform } \\
\text { er oil }\end{array}$ & $\begin{array}{l}\text { Laboratory, pilot } \\
\text { scale, and field } \\
\text { experiments / } \\
\text { Spiked and real } \\
\text { contaminated soils } \\
\text { in field experiments } \\
\text { (in situ, ex situ) }\end{array}$ & $\begin{array}{l}\text { Biostimulation (N, P, } \\
\text { K) }\end{array}$ & $\begin{array}{l}\text { Endogenous microbiota / } \\
\text { RAMEB }\end{array}$ & $\begin{array}{l}99 \% \text { transformer oil } \\
\text { removal in field } \\
\text { experiment in situ } \\
\text { after } 47 \text { weeks. } \\
\text { Decrease in toxicity } \\
\text { after } 24 \text { weeks. }\end{array}$ & $\begin{array}{l}\text { Molnar et } \\
\text { al. (2005) }\end{array}$ \\
\hline $\begin{array}{l}\text { phenol, } \\
\text { cresol, } \\
\text { DMP }\end{array}$ & $\begin{array}{l}\text { Laboratory/ } \\
\text { Real contaminated } \\
\text { soils ( } 3 \text { ) }\end{array}$ & $\begin{array}{l}\text { Bioaugmentation } \\
\text { Biostimulation } \\
\text { (macro- and } \\
\text { micronutrients) }\end{array}$ & $\begin{array}{l}\text { Cultures of exogenous } \\
\text { bacterial strains and } \\
\text { microbial consortia / } \\
\text { Hydroxypropyl- } \beta- \\
\text { cyclodextrin }\end{array}$ & $\begin{array}{l}\text { No difference in } \\
\text { phenolic compounds } \\
\text { degradation with } \\
\text { added } \\
\text { microorganisms, but } \\
\text { greatly enhanced by } \\
\text { addition of HPBCD } \\
\text { and nutrients. }\end{array}$ & $\begin{array}{l}\text { Allan et al. } \\
\text { (2007) }\end{array}$ \\
\hline $\begin{array}{l}\text { Diesel and } \\
\text { engine oils }\end{array}$ & $\begin{array}{l}\text { Laboratory and field } \\
\text { experiments / } \\
\text { Real contaminated } \\
\text { soil }\end{array}$ & $\begin{array}{l}\text { Biostimulation (N, } \\
\text { P) }\end{array}$ & $\begin{array}{l}\text { Endogenous microbiota / } \\
\text { RAMEB }\end{array}$ & $\begin{array}{l}10.000 \mathrm{mg} \mathrm{kg}^{-1} \text { of } \\
\mathrm{EPH} \text { was reduced to } \\
3.400 \mathrm{mg} \mathrm{kg}^{-1} \text { after } \\
85 \text { weeks }\end{array}$ & $\begin{array}{l}\text { Leitgib et al. } \\
\text { (2008) }\end{array}$ \\
\hline $\begin{array}{l}\text { Transform } \\
\text { er oil }\end{array}$ & $\begin{array}{l}\text { field experiments / } \\
\text { Real contaminated } \\
\text { soil }\end{array}$ & $\begin{array}{l}\text { Biostimulation (N, P, } \\
\text { K) }\end{array}$ & $\begin{array}{l}\text { Endogenous microbiota / } \\
\text { RAMEB }\end{array}$ & $\begin{array}{l}\text { Technology } \\
\text { assessment tool that } \\
\text { evaluates the } \\
\text { technological-, } \\
\text { environmental-, } \\
\text { eco- and cost- } \\
\text { efficiency of the } \\
\text { technology after } 47 \\
\text { weeks treatment. }\end{array}$ & $\begin{array}{l}\text { Gruiz et al. } \\
\text { (2009) }\end{array}$ \\
\hline $\begin{array}{l}\text { Diesel and } \\
\text { engine oils }\end{array}$ & $\begin{array}{l}\text { Field experiments / } \\
\text { Real contaminated } \\
\text { soil }\end{array}$ & $\begin{array}{l}\text { Biostimulation }(\mathrm{N}, \\
\text { P) }\end{array}$ & $\begin{array}{l}\text { Endogenous microbiota / } \\
\text { RAMEB }\end{array}$ & $\begin{array}{l}\text { Similar to Leitgib et } \\
\text { al. (2008). } \\
\text { Significant drop on } \\
\text { total nitrogen } \\
\text { content due to high } \\
\text { activity of anaerobic } \\
\text { microbes. }\end{array}$ & $\begin{array}{l}\text { Fenyvesi et } \\
\text { al. (2009b) }\end{array}$ \\
\hline $\begin{array}{l}\text { Transform } \\
\text { er oil }\end{array}$ & $\begin{array}{l}\text { Laboratory, pilot } \\
\text { scale, and field } \\
\text { experiments / } \\
\text { Spiked and real } \\
\text { contaminated soils } \\
\text { in field experiments } \\
\text { (in situ, ex situ) }\end{array}$ & $\begin{array}{l}\text { Biostimulation (N, P, } \\
\text { K) }\end{array}$ & $\begin{array}{l}\text { Endogenous microbiota / } \\
\text { RAMEB }\end{array}$ & $\begin{array}{l}\text { Similar to Molnar et } \\
\text { al. (2005) }\end{array}$ & $\begin{array}{l}\text { Molnar et } \\
\text { al. (2009) }\end{array}$ \\
\hline $\begin{array}{l}\text { Hexadecan } \\
\text { o }\end{array}$ & $\begin{array}{l}\text { Laboratory/ } \\
\text { Artificially spiked }\end{array}$ & Bioaugmentation & $\begin{array}{l}\text { Exogenous bacterial } \\
\text { strain / }\end{array}$ & $\begin{array}{l}\text { HPBCD had no } \\
\text { impact on }\end{array}$ & $\begin{array}{l}\text { Stroud et al. } \\
(2009)\end{array}$ \\
\hline
\end{tabular}




\begin{tabular}{|c|c|c|c|c|c|}
\hline & soil & & $\begin{array}{l}\text { Hydroxypropyl- } \beta- \\
\text { cyclodextrin }\end{array}$ & $\begin{array}{l}\text { hexadecane } \\
\text { degradation. }\end{array}$ & \\
\hline Diesel oil & $\begin{array}{l}\text { Laboratory/ } \\
\text { Artificially spiked } \\
\text { soil }\end{array}$ & $\begin{array}{l}\text { Bioaugmentation } \\
\text { and biostimulation } \\
\text { (municipal solid } \\
\text { waste compost) }\end{array}$ & $\begin{array}{l}\text { Exogenous bacterial } \\
\text { consortium / } \\
\beta \text {-cyclodextrin }\end{array}$ & $\begin{array}{l}87 \% \text { degradation } \\
\text { after } 120 \text { days with } \\
\text { only compost; } 95 \% \\
\text { with compost + } \\
\text { consortium; } \\
\text { increase to } 38 \% \\
\text { when BCD was } \\
\text { added. }\end{array}$ & $\begin{array}{l}\text { Taccari et } \\
\text { al. (2012) }\end{array}$ \\
\hline
\end{tabular}

Table 4. Selected reports on the use of cyclodextrins in bioremediation by microorganisms of soils contaminated by diesel, transformer oil and other organic contaminants. 


\begin{tabular}{|c|c|c|c|c|c|}
\hline $\begin{array}{l}\text { Contam } \\
\text { inants }\end{array}$ & $\begin{array}{l}\text { Scale/ } \\
\text { Contaminatio } \\
\mathbf{n}\end{array}$ & $\begin{array}{l}\text { Bioremediatio } \\
\text { n Technique }\end{array}$ & $\begin{array}{l}\text { Microorganisms / } \\
\text { Plants / CDs }\end{array}$ & Achievements & $\begin{array}{l}\text { Referen } \\
\text { ces }\end{array}$ \\
\hline PAHs & $\begin{array}{l}\text { Field scale ( } 6 \\
\text { months) / } \\
\text { Artificially spiked } \\
\text { soil }\end{array}$ & $\begin{array}{l}\text { Bioaugmentation } \\
\text { and biostimulation } \\
\text { (urea) }\end{array}$ & $\begin{array}{l}\text { Exogenous microbial } \\
\text { consortium / Soybean / } \\
\beta \text {-cyclodextrin }\end{array}$ & $\begin{array}{l}\text { PAHs } \\
\text { bioremediation in } \\
\text { soil was improved } \\
\text { by soybean plants. } \\
\text { Uptake of } \\
\text { hydrocarbons in } \\
\text { soybeans. }\end{array}$ & $\begin{array}{l}\text { Bardi et al. } \\
\text { (2007) }\end{array}$ \\
\hline$p, p^{\prime}-D D E$ & $\begin{array}{l}\text { Field scale ( } 3 \\
\text { months) / } \\
\text { Real contaminated } \\
\text { soil }\end{array}$ & - & $\begin{array}{l}\text { Endogenous } \\
\text { microorganisms / } \\
\text { Cucurbita pepo (zucchini) } \\
\text { / } \beta \text {-cyclodextrin }\end{array}$ & $\begin{array}{l}\text { BCD had no effect } \\
\text { on } \\
\text { DDE } \\
\text { phytoremediation }\end{array}$ & $\begin{array}{l}\text { White et al. } \\
\text { (2007) }\end{array}$ \\
\hline PCBs & $\begin{array}{l}\text { Greenhouse } \\
\text { experiments }(120 \mathrm{~d}) \\
\text { / Real } \\
\text { contaminated soil }\end{array}$ & $\begin{array}{l}\text { Biostimulation } \\
\left(\mathrm{KH}_{2} \mathrm{PO} 3, \mathrm{NH}_{4} \mathrm{NO}_{3}\right)\end{array}$ & $\begin{array}{l}\text { Endogenous } \\
\text { microorganisms / rice, } \\
\text { alfalfa, ryegrass and tall } \\
\text { fescue / RAMEB }\end{array}$ & $\begin{array}{l}25-28 \% \text { removal in } \\
\text { rhizosphere soil, } 10- \\
17 \% \text { in non- } \\
\text { rhizosphere soil, } 7 \% \\
\text { in unplanted soil. } \\
27-37 \% \text { in } \\
\text { rhizosphere + } \\
\text { RAMEB. }\end{array}$ & $\begin{array}{l}\text { Shen et al. } \\
\text { (2009) }\end{array}$ \\
\hline PCBs & $\begin{array}{l}\text { Greenhouse } \\
\text { experiments (120 d) } \\
\text { / Artificially spiked } \\
\text { soil }\end{array}$ & $\begin{array}{l}\text { Biostimulation } \\
\left(\mathrm{KH}_{2} \mathrm{PO}_{2}, \mathrm{NH}_{4} \mathrm{NO}_{3}\right)\end{array}$ & $\begin{array}{l}\text { Endogenous } \\
\text { microorganisms / alfalfa, } \\
\text { ryegrass, tall fescue, rice } \\
\text { / } \beta \text {-cyclodextrin, RAMEB }\end{array}$ & $\begin{array}{l}\text { Plants increased soil } \\
\text { biological activity. } \\
10 \% \text { PCBs degraded } \\
\text { with BCD ( } 1 \% \mathrm{w} / \mathrm{w}) \text {, } \\
\text { but } 38 \% \text { with } \mathrm{BCD}+ \\
\text { ryegrass. More } \\
\text { degradation in soil } \\
\text { than plant uptake. }\end{array}$ & $\begin{array}{l}\text { Chen et al. } \\
(2010)\end{array}$ \\
\hline $\begin{array}{l}\text { Organochl } \\
\text { orine } \\
\text { pesticides } \\
\text { (OCPs) } \\
\text { + PTEs }\end{array}$ & $\begin{array}{l}\text { Greenhouse } \\
\text { experiments }(90 \mathrm{~d}) / \\
\text { Real contaminated } \\
\text { soil }\end{array}$ & $\begin{array}{l}\text { Biostimulation } \\
\text { (glucose, biphenyl, } \\
\mathrm{KH}_{2} \mathrm{PO}_{2}, \mathrm{NH}_{4} \mathrm{NO}_{3} \text { ) }\end{array}$ & $\begin{array}{l}\text { Endogenous } \\
\text { microorganisms / Vetiver } \\
\text { grass / Carboxymethyl- } \beta \text { - } \\
\text { cyclodextrin CMBCD) }\end{array}$ & $\begin{array}{l}\text { Washing with } \\
\text { CMBCD extracted } \\
94.7 \% \text { OCPs. Vetiver } \\
\text { grass cultivated to } \\
\text { degrade } 35 \% \text { of the } \\
\text { residual OCPs. }\end{array}$ & $\begin{array}{l}\text { Ye at al. } \\
\text { (2014b) }\end{array}$ \\
\hline Cyanophos & $\begin{array}{l}\text { Greenhouse } \\
\text { experiments ( } 9 \text { d) / } \\
\text { Artificially spiked } \\
\text { soil }\end{array}$ & & $\begin{array}{l}\text { Endogenous } \\
\text { microorganisms / } \\
\text { Plantago major L. / } \\
\text { Hydroxypropyl-ß- } \\
\text { cyclodextrin }\end{array}$ & $\begin{array}{l}\text { 17\% removed from } \\
\text { soil after } 3 \text { days, } \\
46 \% \text { from soil + } \\
\text { plant, } 65 \% \text { from soil } \\
+ \text { plant }+ \text { HPBCD. } 3 \\
\text { metabolites } \\
\text { detected in roots } \\
\text { and leaf samples. }\end{array}$ & $\begin{array}{l}\text { Romeh } \\
\text { (2015) }\end{array}$ \\
\hline $\begin{array}{l}\text { Phenanthr } \\
\text { ene }+\mathrm{Pb}\end{array}$ & $\begin{array}{l}\text { Greenhouse } \\
\text { experiments ( } 90 \mathrm{~d}) / \\
\text { Artificially spiked } \\
\text { soil }\end{array}$ & 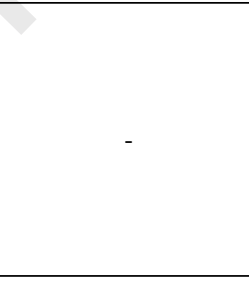 & $\begin{array}{l}\text { Endogenous } \\
\text { microorganisms / } \\
\text { Ryegrass / Cysteine- } \beta \text { - } \\
\text { cyclodextrin (CBCD) }\end{array}$ & $\begin{array}{l}\text { Accumulation of } \\
\mathrm{PHE} \text { and } \mathrm{Pb} \text { in } \\
\text { shoots and roots. In } \\
\text { unplanted soil } 18 \% \\
\text { PHE removed ( } 25 \% \\
\mathrm{~Pb}) \text {. In planted soil } \\
48 \% \mathrm{PHE} \text { removed } \\
\text { (56\% } \mathrm{Pb}) \text {. }\end{array}$ & $\begin{array}{l}\text { Wang et al. } \\
\text { (2015) }\end{array}$ \\
\hline BDE-209 & $\begin{array}{l}\text { Greenhouse } \\
\text { experiments ( } 180 \mathrm{~d}) \\
\text { / Artificially spiked } \\
\text { sediments }\end{array}$ & - & $\begin{array}{l}\text { Endogenous } \\
\text { microorganisms / Scirpus } \\
\text { validus Vahl (Acuatic } \\
\text { macrophyte) / } \beta \text { - } \\
\text { cyclodextrin } \\
\end{array}$ & $\begin{array}{l}\text { No significant } \\
\text { degradation of BDE- } \\
209 \text { in the presence } \\
\text { of } B C D\end{array}$ & $\begin{array}{l}\text { Zhao et al. } \\
\text { (2017) }\end{array}$ \\
\hline DDT & $\begin{array}{l}\text { Greenhouse } \\
\text { experiments (10 } \\
\text { weeks) / Real } \\
\text { contaminated soil }\end{array}$ & 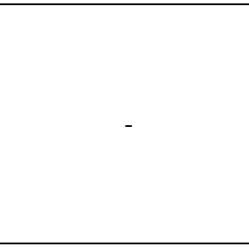 & $\begin{array}{l}\text { Endogenous } \\
\text { microorganisms / Two } \\
\text { native grasses / } \\
\text { Hydroxypropyl- } \beta \text { - } \\
\text { cyclodextrin }\end{array}$ & $\begin{array}{l}\text { HPBCD did not } \\
\text { promoted DDT } \\
\text { degradation in soil, } \\
\text { but enhanced DDT } \\
\text { phytoextraction. } \\
\text { DDT leached in soil } \\
\text { columns. } \\
\end{array}$ & $\begin{array}{l}\text { Dahmer et } \\
\text { al. (2018) }\end{array}$ \\
\hline $\begin{array}{l}\text { BDE-209+ } \\
\text { Cd }\end{array}$ & $\begin{array}{l}\text { Greenhouse } \\
\text { experiments (65d) / } \\
\text { Artificially spiked } \\
\text { soil }\end{array}$ & $\begin{array}{l}\text { Bioaugmentation } \\
\text { and biostimulation } \\
\text { (Hoagland-Arnon } \\
\text { nutrient solution } \\
20 \% \text { ) }\end{array}$ & $\begin{array}{l}\text { Two arbuscular } \\
\text { Mycorrhizal fungi (AMF) } \\
\text { / Solanum nigrum / } \beta- \\
\text { cyclodextrin }\end{array}$ & $\begin{array}{l}\text { BCD increased shoot } \\
\text { biomass and Cd } \\
\text { contents in shoots. } \\
\text { BDE-209 adsorbed } \\
\text { by root, }\end{array}$ & $\begin{array}{l}\text { Li et al. } \\
\text { (2018a) }\end{array}$ \\
\hline
\end{tabular}




\begin{tabular}{|c|c|c|c|c|c|}
\hline & & & & $\begin{array}{l}\text { translocated to } \\
\text { shoots and } \\
\text { degraded to lower } \\
\text { brominated } \\
\text { products. } \\
\text { Inoculation has not } \\
\text { influence. }\end{array}$ & \\
\hline $\begin{array}{l}\text { BDE-209+ } \\
\text { Cd }\end{array}$ & $\begin{array}{l}\text { Greenhouse } \\
\text { experiments ( } 65 \mathrm{~d}) \text { / } \\
\text { Artificially spiked } \\
\text { soil }\end{array}$ & $\begin{array}{l}\text { Bioaugmentation } \\
\text { and biostimulation } \\
\text { (Hoagland-Arnon } \\
\text { nutrient solution } \\
20 \% \text { ) }\end{array}$ & $\begin{array}{l}\text { White-rot fungus / } \\
\text { Amaranth / } \\
\beta \text {-cyclodextrin }\end{array}$ & $\begin{array}{l}5.4 \% \text { degraded in } \\
\text { unplanted soil; } 28 \% \\
\text { in cultivated soil; } \\
56 \% \text { in cultivated } \\
\text { soil + fungus; } 66 \% \\
\text { with fungus + BCD } \\
1.2 \% \text { ( } 1.3 \% \text { Cd } \\
\text { removal). }\end{array}$ & $\begin{array}{l}\text { Li et al. } \\
\text { (2018b) }\end{array}$ \\
\hline $\begin{array}{l}\text { Fluorene + } \\
\text { Cd }\end{array}$ & $\begin{array}{l}\text { Greenhouse } \\
\text { experiments ( } 90 \mathrm{~d}) / \\
\text { Artificially spiked } \\
\text { soil }\end{array}$ & - & $\begin{array}{l}\text { Endogenous } \\
\text { microorganisms / Alfalfa } \\
\text { / Aspartic acid- } \beta \text { - } \\
\text { cyclodextrin (ACD) }\end{array}$ & $\begin{array}{l}17 \% \text { FLU removed } \\
\text { from unplanted soil } \\
(4 \% \text { Cd); } 46 \% \text { in } \\
\text { cultivated soil ( } 26 \% \\
\text { Cd); } 67 \% \text { in } \\
\text { cultivated soil + ACD } \\
(35 \% \text { Cd). }\end{array}$ & $\begin{array}{l}\text { Wang et al. } \\
\text { (2018) }\end{array}$ \\
\hline $\begin{array}{l}\text { Cypermeth } \\
\text { rin (CYP) }\end{array}$ & $\begin{array}{l}\text { Greenhouse } \\
\text { experiments ( } 65 \text { d) / } \\
\text { Artificially spiked } \\
\text { soil }\end{array}$ & - & $\begin{array}{l}\text { Endogenous } \\
\text { microorganisms / } \\
\text { Plantago major / } \\
\text { Hydroxypropyl- } \beta \text { - } \\
\text { cyclodextrin }\end{array}$ & $\begin{array}{l}62 \% \text { CYP removed } \\
\text { from unplanted soil; } \\
68 \% \text { in cultivated } \\
\text { soil; } 80 \% \text { in } \\
\text { cultivated soil + } \\
\text { HPBCD }\end{array}$ & $\begin{array}{l}\text { Aioub et al. } \\
\text { (2019) }\end{array}$ \\
\hline $\begin{array}{l}\text { BDE-209+ } \\
\text { Cd }\end{array}$ & $\begin{array}{l}\text { Greenhouse } \\
\text { experiments (14 d) / } \\
\text { Artificially spiked } \\
\text { soil }\end{array}$ & $\begin{array}{l}\text { Bioaugmentation } \\
\text { and biostimulation } \\
\text { (Hoagland-Arnon } \\
\text { nutrient solution } \\
20 \% \text { ) }\end{array}$ & $\begin{array}{l}\text { Arbuscular Mycorrhizal } \\
\text { fungus (AMF) / } \\
\text { Amaranth / } \beta- \\
\text { cyclodextrin }\end{array}$ & $\begin{array}{l}5.5 \% \text { degraded in } \\
\text { unplanted soil; } 27 \% \\
\text { in cultivated soil; } \\
39 \% \text { in cultivated } \\
\text { soil + fungus; } 45 \% \\
\text { with fungus + BCD } \\
0.4 \% \text {. } \\
\text { Cd accumulation in } \\
\text { shoots and roots }\end{array}$ & $\begin{array}{l}\text { Li et al. } \\
\text { (2019) }\end{array}$ \\
\hline
\end{tabular}

Table 5. Selected reports on the use of cyclodextrins in phytoremediation of soils contaminated by organic pollutants. 


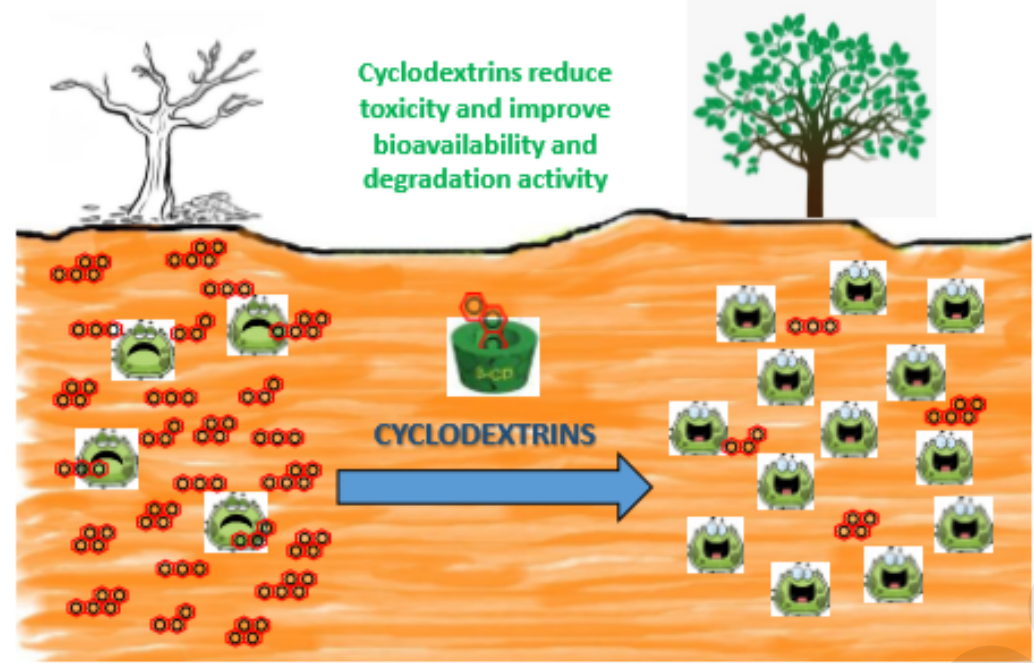

CYCLODEXTRINS ASSISTED BIOREMEDIATION 


\section{Highlights}

Many soil decontamination techniques can be improved using Cyclodextrins (CDs)

CDs demonstrated increasing organic contaminants bioavailability in soil bioremediation.

Bioremediation using CDs can be a cost-effective and environmentally friendly alternative.

The majority of CDs scientific studies are still at the lab-scale stage.

Scaling up CD technology is needed to know their real cost and efficacy. 